\title{
The Use of Derivatives in the Spanish Mutual Fund Industry*
}

\author{
José M. Marín \\ Universitat Pompeu Fabra and CREA \\ jose.marin@upf.edu \\ Thomas A. Rangel \\ Universitat Pompeu Fabra \\ thomas.rangel@upf.edu
}

November 2006

\begin{abstract}
We study the use of derivatives in the Spanish mutual fund industry. The picture that emerges from our analysis is rather negative. In general, the use of derivatives does not improve the performance of the funds. In only one out of eight categories we find some (very weak and not robust) evidence of superior performance. In most of the cases users significantly underperform non users. Furthermore, users do not seem to exhibit superior timing or selectivity skills either, but rather the contrary. This bad performance is only partially explained by the larger fees funds using derivatives charge. Moreover, we do not find evidence of derivatives being used for hedging purposes. We do find evidence of derivatives being used for speculation. But users in only one category exhibit skills as speculators. Finally, we find evidence of derivatives being used to manage the funds' cash inflows and outflows more efficiently.
\end{abstract}

JEL Classification: G11,G2

Keywords: Mutual Funds, Derivative use, Risk Management.

*We thank participants at Simposio de Análisis Económico and the Summer School in Empirical Asset Pricing at the Center For Financial Studies for their helpful comments. José Marín thanks the Spanish Ministry of Science and Technology (SEJ2005-03924) and CREA for financial support. Thomas Rangel thanks Conacyt for financial support. 


\section{Introduction}

Spanish mutual funds are heavy users of derivatives. Figure 1 provides some statistics on derivatives usage. The fraction of funds using derivatives has steadily increased during the last ten years. By 2005 some $60 \%$ of the Spanish mutual funds had some derivatives position in their portfolio. Even stronger is the increase in the extent of derivatives usage. The fraction of the total notional of derivatives positions to the net asset value of all funds increased from $2.7 \%$ to $15.8 \%$ during the same period. These figures sharply contrast with the figures obtained elsewhere. For instance, in their study of usage in the US market, Koski and Pontiff (1999) estimate that in 1993 only $21 \%$ of US mutual funds were users. In another study, Johnson and Yu (2004) estimate that the extent of usage in the Canadian market in 1998 ranges from $1.28 \%$ to $2.32 \%$. Finally, Pinnuck (2004) reports a maximum extent of usage of $3.34 \%$ in the Australian market during the period 1990 to $1997 .^{1}$ On the other hand, the Spanish mutual fund industry is quite large. In Figure 1 we also report the total net asset value under management by Spanish mutual funds relative to the total market capitalization of the Spanish market. Assets under management represented $100 \%$ of the Spanish market capitalization in the mid nineties. The figure has fallen to $60 \%$ by 2005. But this mostly reflects the large increase in the size of the Spanish market during the period. Assets under management amounted to 240 billion Euros at the beginning of 2005. An impressive figure. Given the order of magnitude of the Spanish fund industry and the extensive use of derivatives, it is quite surprising the lack of research analyzing the impact of derivatives usage on risk and performance, which is the main goal we pursue in this paper.

Derivatives can be viewed as neutral or potentially performance-enhancing investment vehicles. Derivatives are neutral when, for instance, managers use them to

\footnotetext{
${ }^{1}$ These last two papers use a different measure of extent of usage than the one we use in this paper. Johnson and $\mathrm{Yu}(2004)$ measures extent of usage as total market value to the total asset position of all funds and Pinnuck (2004) as the total option delta position to net asset value of all funds.
} 


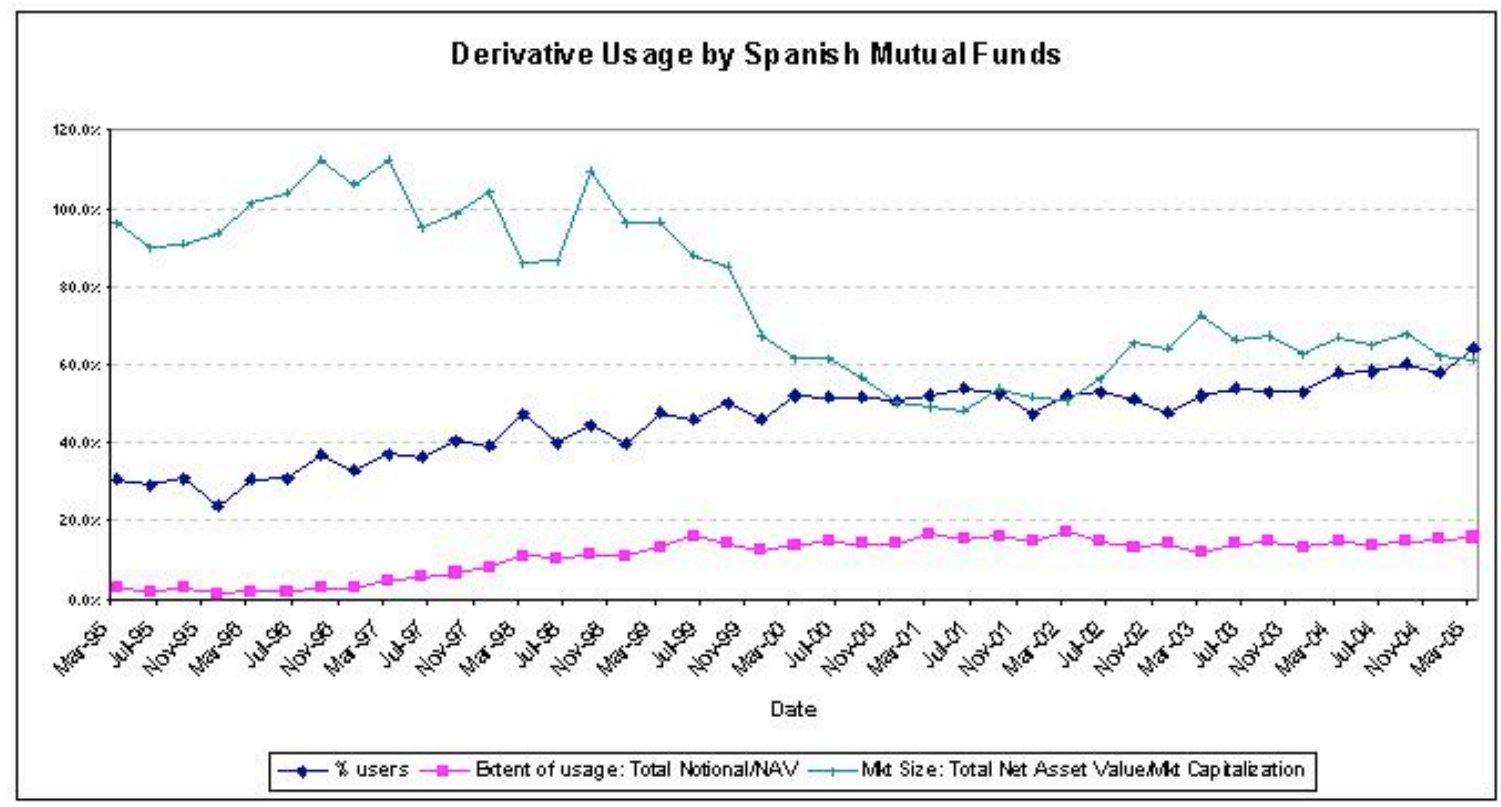

Figure 1: Derivatives Usage by Spanish Mutual Funds.

This table reports the percentage of users as the number of funds that reported some derivative position in a quarter divided by the total number of funds registered in the same quarter. Extent of derivative usage is measured as the total notional positions in derivatives of all funds per quarter divided by the total net asset value of all funds registered in the same quarter. The size of the mutual fund industry is measured as the total net asset value of all funds in the quarter divided by the Spanish market capitalization as of the end of the same quarter. The sample covers the period from March 1995 to March 2005. Fund data is obtained from the Spanish Security and Exchange Commission, CNMV. The market capitalization data is obtained from the Spanish Central Bank, Banco de España.

synthesize cash positions. If managers were just doing this we should not expect significant differences in the return distributions of users versus non-users of derivatives. Furthermore, we should not observe significant differences in performance evaluation measures for users versus non-users of derivatives. But derivatives can also be used as an instrument for speculation, for risk management or to profit from market imperfections, such as transaction costs, or to better manage the fund's cash inflows and outflows. In these cases the return distributions and performance evaluation measures of users and non users can be quite different. In this paper we shed light on this issue by performing a comprehensive empirical analysis of derivatives usage in the Spanish mutual fund industry. To achieve this goal we focus on the differences 
in return distributions and performance of users versus non users of derivatives. We now turn to briefly relate these two variables to the alternative uses of derivatives.

Derivatives offer high leverage power and are often used as speculative instruments. Indeed this is the view of derivatives that has received the largest amount of attention in the media, with the extensive coverage of dramatic cases such as Enron, Daiwa Bank, or Sumitomo Corp (Tschoegl (2003), Johnson and Yu 2004)), which has contributed to the popular perception of derivatives as risky, even dangerous, instruments that may portray dramatic losses. ${ }^{2}$ To understand the impact of speculative usage on return distributions and performance it is worthwhile thinking in users as market timers. It is well recognized that market timing per se adds volatility and that skillful timing adds skewness to the portfolio return. Furthermore, timing skills can be detected using several performance evaluation measures. On the other hand, some derivatives, such as options, are specially suitable for risk management and hedging. In particular, derivatives can be used to reduce the tails of the distribution of returns, that is, to decrease the effect of extreme market outcomes on portfolio returns. Hence, we should expect the return distribution of users to exhibit smaller volatility, shortfall risk and kurtosis than the one of non-users, when derivatives are used for hedging purposes.

Derivatives can also be used to reduce transaction costs or to manage cashflows efficiently. Regarding costs, it is well know that, for instance, the typical roundtrip cost on index futures is well below the cost of trading the index constituents in the spot market. If managers were using derivatives for this purpose we should expect performance to improve. Regarding the latter issue, there is ample evidence that funds cash inflows and outflows are associated to past performance. Ippolito (1992) shows that funds receive cash inflows after periods of good performance, and suffer cash outflows after periods of bad performance. If fund managers are reluctant or unable to invest and divest securities in response to unexpected cash flows, then cash

\footnotetext{
${ }^{2}$ For instance, see Koski and Pontiff (1999).
} 
flows will influence the risk of the fund. Derivatives can be used to manage the impact of performance on risk by managing cash flows more efficiently. This is the cash flow management hypothesis proposed by Koski and Pontiff (1999). Very much related with this hypothesis is the incentive gaming hypothesis in fund management. Brown et al. (1996), Chevalier and Ellison (1997) and Koski and Pontiff (1999) study the relation of past performance on changes in risk. They conclude that as the evaluation period approaches, managers have an incentive to increase risk after periods of bad performance and decrease risk after periods of good performance. Derivatives may be used to either dampen or increase the fund's risk. Hence derivatives can be used in a similar fashion for both cash flow management and incentive gaming.

To shed light on these issues we perform an extensive empirical study of derivatives usage in the Spanish mutual fund industry. Our study covers the period March 1995 to March 2005 and analyzes the universe of funds in the Spanish market. ${ }^{3}$ It is indeed the first study that uses the whole set of funds in a country and for such an extended period. Studies for other countries either focus on the cross section of funds at some particular point in time or just use the time series of a subset of funds. This is important as our study does not suffer from sample selection biases. We classify the 18 official fund types into the following fund categories: Balanced Domestic, Balanced International, Domestic Equity, European Equity, Foreign Equity, Fixed Income, Money Market and Global funds. Within each category we separate users from non users of derivatives. In several parts of the paper we use two definitions of usage. We call users to those funds that have used derivatives at least once during their existence. Since many funds use derivatives very rarely, we also define heavy users as those funds that have taken positions in derivatives in more than $75 \%$ of the quarters of their life span and whose average notional positions are in the 75th percentile.

\footnotetext{
${ }^{3}$ The only fund category excluded in our analysis is the case of Guarantee Funds (Fondos Garantizados). We do this for two reasons: first, because the fraction of non-users of derivatives in this category is very small and, second, because of the special structure and objectives of these type of funds.
} 
Our study focuses on four main issues. We first look at the main characteristics associated to derivatives usage. We look at two measures of derivatives usage: the decision to use derivatives and the extent of usage (defined as the fraction of the notional of derivatives positions to the net asset value of the fund). We find that users tend to be funds that: 1) belong to a large family of funds, 2) have other funds in the family using derivatives, 3) charge larger management fees, 4) charge no load fees, 5) are larger and 6) have a lower dividend yield. The first two variables highlight the important role of economies of scale in the decision and extent of usage. In contrast to the previous literature, in the Spanish case management fees play an important role in the decision to be user and in the extent of usage. The higher the management fees the higher the probability of using derivatives and the higher the extent of derivative use. In addition, we are able to distinguish within the set of variables that proxy for economies of scale and establish that the key variable is the existence of other funds in the family using derivatives, rather than the size of the family per se. The extent of usage is increasing with the number of funds in the family, the existence of more users in the family, larger management fees and being younger. These results contrast with those obtained by Johnson and Yu (2004) who find no characteristics associated to the extent of usage.

Second, we perform a comparative study of the risk and performance of users vs. non users of derivatives. We focus on typical mean-variance and market model related performance measures and we also test for selectivity and timing skills in the context of the Treynor-Mazuy (1966) model. The general picture that emerges from this study is quite negative. In only one category, fixed income funds, users exhibit superior performance than non-users and this only in the case of returns before fees. For the rest of categories either there are no significant differences or users perform worst than non users. The previous result remains true when we look at fund returns for heavy users of derivatives. The bad picture improves slightly for some fund categories if we consider before fees returns, but never to the point 
of making derivative users better performers, with the exception of Fixed Income funds. This results sharply contrasts with those obtained in other markets where, in general, no significant differences in performance is appreciated. Regarding timing and selectivity skills users do not seem to exhibit either superior timing or selectivity skills, but rather the contrary. The only exceptions are the users in the Balance Domestic and European Equity categories who exhibit timing skills and users in the Fixed Income category who exhibit selectivity skills.

Since risk has many dimensions beyond the standard deviation of returns and given that ex ante we expect derivatives usage to affect higher order moments of the distribution, we perform a comparative study of the return distributions of users versus non users of derivatives. This study focuses on the four central moments and the two $10 \%$ tails of the distributions of returns. The analysis of the moments of the distribution of returns does not support the view that mutual funds use derivatives for risk management purposes. On the contrary, stronger evidence is found that derivatives are used either for speculative purposes or to synthesize the typical cash positions in the category. In general, funds that use derivatives for speculation are not very successful at this task.

To complete our picture on derivatives usage we perform a final exercise testing the incentive gaming hypothesis versus the cashflow management hypothesis. The evidence on derivatives usage by Spanish mutual funds favors the cashflow management hypothesis. This result is consistent with the one obtained in Koski and Pontiff (1999) in their study of the US equity mutual funds. Our study also suggests that the management of cashflows is done by taking positions in market index derivatives.

The rest of this paper is organized as follows. In section 2 we briefly review the literature on the use of derivatives by mutual funds. In section 3 we describe the institutional setting of the Spanish mutual fund industry and the data used in the present study. Section 4 is dedicated to the study of the determinants of derivatives usage. The comparative study on risk and performance is executed in section 5, while 
section 6 is dedicated to the comparative study of the return distributions. In section 7 we test the incentive gaming versus the cashflow management hypothesis. The final section 8 is dedicated to some concluding remarks.

\section{$2 \quad$ Related Literature}

The existing literature on derivative use by mutual funds is not large and is naturally separated by countries. Koski and Pontiff (1999) analyze the use of derivatives by the US equity mutual funds during the year 1993. To determine if a fund uses derivatives they perform a survey. Johnson and Yu (2004) study the use of derivatives by the equity, fixed-income and foreign equity mutual funds in Canada in 1998. Finally, Pinnuck (2004) examines the use of exchange traded options for a sample of Australian equity mutual funds during the period 1990 to 1997. In this paper we extend the literature on derivative use in Spain by analyzing a richer data set than the previous studies. Our data set includes all fund categories, contains actual data on derivatives positions and covers the period March 1995 to March 2005.

About the incidence of derivative use among the mutual funds there are some differences in the findings. Koski and Pontiff (1999) and Johnson and Yu (2004) coincide that the use of derivatives is not very extended, they find that only about $21 \%$ of funds use derivatives. On the other hand, Pinnuck (2004) finds that $60 \%$ of funds in his sample use derivatives. In the present paper, we find that derivative usage is the Spanish case is more extended. Figure 1 shows that by 2005 some $64 \%$ of all funds in the industry use derivatives. Related to the extent of derivative use, only Johnson and Yu (2004) and Pinnuck (2004) report some figures. They use different measures but both conclude that the extent of derivative use is small. Johnson and Yu (2004) report ranges form $1.28 \%$ to $2.32 \%$, while Pinnuck (2004) reports a maximum of $3.34 \%{ }^{4}$ In the present paper we measure the extent of usage as the notional

\footnotetext{
${ }^{4}$ Johnson and Yu's measure is total market value of derivatives divided by total asset value, while Pinnuck's measure is the total delta of the options positions divided by net asset value.
} 
amount in derivatives divided by total net asset value. The values of this measure at the fund level range from zero to $100 \%$, with an average value of $26 \%$.

In relation to the fund characteristics associated to the decision and extent of derivative usage, Koski and Pontiff (1999) study the fund characteristics associated with the decision to use derivatives. They find that funds with greater trading activity, as measured by turnover, are more likely to use derivatives, and funds that are members of families are more likely to use derivatives. Johnson and Yu (2004) find that for fixed income funds and foreign equity funds the decision is related to fund age, younger funds being more likely to use derivatives. For domestic equity funds derivative usage is more likely for larger funds and with lower dividend yields and whether the fund is an Aggressive Growth fund. They do not find any relationship between the extent of derivative use and fund characteristics. Pinnuck (2004) finds only weak evidence that larger funds are more likely to use options. In this paper we analyze both the decision to use and the extent of usage of derivatives. We find that the decision to use derivatives is related to the number of fund in a family, and that the most important characteristic is the existence of another fund in the family using derivatives. Larger and older funds increase the probability of using derivatives. No load funds and funds that have low dividend ratios are more likely to use derivatives. In addition, funds that charge larger management fees are also more likely to include derivatives among their positions. In contrast to the findings in Johnson and $\mathrm{Yu}(2004)$ we identify several characteristics associated to the extent of usage. In particular charging larger management fees and having lower dividend yield ratios is associated with a greater extent of derivative use.

Related to other risk-performance measures, Koski and Pontiff (1999) report no systematic differences among users and nonusers. Only Aggressive Growth funds have a lower beta than nonusers. They do not compute the Jensen's alpha, but they compute the alpha following the Ferson and Shadt (1996) and Shanken (1990) model of conditional betas. They do not find any differences between users and nonusers of 
derivatives. Johnson and $\mathrm{Yu}$ (2004) report a lower and negative alpha and a larger beta for users of derivatives of Domestic Equity funds, but once they control for warrants, the effect is lost and no differences prevail. Foreign Equity funds show no differences in their alpha and beta. They are not able to say anything about the Fixed Income funds, since their alphas and betas are given by the data source, and they do not provide these parameters. The results obtained in the present paper are quite different. We study both users and heavy users of derivatives and look at fund returns before and after fees. We find that in four fund categories users perform significantly worst than non users and that in there categories there are no significant differences. Only users, and specially heavy users, in the fixed income category exhibit superior performance. These funds exhibit larger sharpe ratios, larger alphas and larger appraisal ratios.

Regarding market timing, Koski and Pontiff (1999) report no differences between users and nonusers of derivatives. Johnson and Yu (2004) do not compute the market timing coefficient. Pinnuck (2004) does not mention anything related to market timing. In the Spanish market the evidence on market timing is mixed. For most of the fund categories the evidence points at worst timing and selectivity skills of users than non users. In two categories the evidence favors users and in the rest of the cases there no significant differences.

Regarding return distributions, Koski and Pontiff (1999) conclude that there are no systematic differences among users and nonusers of derivatives. Only Small Company funds have a smaller and more negative kurtosis and the Aggressive Growth funds have a larger and positive kurtosis. They do not compute the simple annual mean return. Johnson and $\mathrm{Yu}$ (2004) compute the annual mean return and the standard deviation but not the other higher moments. They find differences among fund types. Fixed Income funds have a larger mean return and a larger standard deviation. Foreign Equity funds have a lower mean return, and Domestic Equity funds have a lower mean return but a higher standard deviation. Pinnuck (2004) does not clearly 
state if he made this analysis. The evidence for the Spanish market is that derivatives do affect the four main central moments of the distribution of returns.

Finally, in relation to the inter-temporal effect of derivatives on the change in risk, only Koski and Pontiff (1999) do an analysis of this type. They conclude that derivative use reduces the change in risk. They interpret this result as being consistent with their stated hypothesis of derivative use for managing cash flows more efficiently. In Spain, restricting the sample to all but the fixed income funds, the results are very similar to those found in Koski and Pontiff (1999). The evidence supports the hypothesis that users of derivatives reduce their inter-temporal change in risk by relying on derivatives.

\section{Institutional Setting and Database Description}

\subsection{Institutional Setting of the Spanish Mutual Fund Indus- try}

Mutual funds in Spain are regulated and supervised by the Comisión Nacional del Mercado de Valores (CNMV), the Spanish equivalent to the US SEC. According to regulation in place, ${ }^{5}$ mutual funds are not allowed to have commitments in derivatives above the fund's net asset value, in addition the premium paid for non-linear derivatives cannot exceed 10\% of the fund's net asset value, and Money Market funds are only allowed to use derivatives for hedging purposes. The first two restrictions are not compulsory if the fund pursues a specific return objective that has been guaranteed by a third party. In any case we expect to find evidence that Money Market funds do not use derivatives for speculation, but for hedging purposes. The evidence on Money Market funds partially supports this expectation. Money Market funds that use derivatives are indistinguishable from Money Market funds that do not use

\footnotetext{
${ }^{5}$ Orden Ministerial, de 6 de julio de 1992; Orden Ministerial, de 10 de junio de 1997; Circular $3 / 98$, de 22 de septiembre.
} 
derivatives. The CNMV requires mutual funds to report the end of quarter portfolio of the fund including both on balance and off balance positions.

\subsection{Database Description}

The source of the data is the Spanish Security and Exchange Commission (CNMV). The database consists of the end of quarter open derivative positions for each open end mutual fund in Spain for the period March 1995 to March 2005. This database includes the whole population of mutual funds. At the end of March 1995 there were 695 funds, by the end of March 2005 there are a total of 2, 623 funds registered. Thus, the number of funds in this ten year period has increased by a factor of almost 4 .

In addition to the open positions in derivatives for each fund, the database includes information on the daily per share net asset value, the fund's family, ${ }^{6}$ the total net asset value, the management fees, ${ }^{7}$ and the fees charged for purchases and redemptions of the fund's shares and the deposit fee. ${ }^{8}$ We complement the database with information on the official fund types assigned by the same governmental agency and the fund's inception date. The fund categories are as of June, 2004. If a fund does not have a category assigned it is dropped out of the sample. Finally, we construct some additional variables, namely the number of funds in the family, if there are more than two funds in the family that report open positions in derivatives, and the dividend yield. There is also information on the notional and market value of the derivative positions, which we aggregate per fund and quarter in order to analyze the extent of derivative use. For most of the positions there is also a brief name or description of the derivative position. Therefore, the database is an extensive and comprehensive set of information, which is ideal to analyze the use of derivatives by the mutual fund industry.

\footnotetext{
${ }^{6} \mathrm{~A}$ fund family is defined as the management company that manages one or more mutual funds.

${ }^{7}$ The management fees are expressed as a percentage of either total net asset value or return, or a combination of both.

${ }^{8}$ In Spain funds pay a deposit fee which is based on the total assets under management and is represented as an annual percentage.
} 
There are 18 official fund types which we aggregate into 9 fund categories for ease of analysis and exposition and to relate our study to those performed for other countries. In Appendix A we describe these official categories. The grouping of the official fund types into categories is based on the definitions of their their percentages invested in different asset classes. The official fund types are: FIAMM, Money Market funds; RFCP, Short Term Fixed Income funds; RFLP, Long Term Fixed Income funds; RFI, International Fixed Income funds; RFM, Balanced Fixed Income funds; RVM, Balanced Equity funds; RFMI, Balanced International Fixed Income funds; RVMI, Balanced International Equity funds; RVN, Domestic Equity funds; RVE, European Equity funds; RVIE, RVIJ, RVIU, RVIM, RVIO, for International Equity funds specializing in the geographical regions Europe, Japan, USA, Emerging Markets, and Other Markets respectively; GRV, GRF, Equity and Fixed Income Guaranteed funds; and FGL, Global funds. ${ }^{9}$ The created new fund categories are Balanced Domestic, Balanced International, Domestic Equity, European Equity, Foreign Equity, Guaranteed, Fixed Income, Money Market, and Specialty.

The database consists of a total of 41 quarters, with a total of 3,383 funds for the whole time period. We drop out all those funds for which we could not assign an official type. ${ }^{10}$ In addition, we only use funds with at least three years of observations and that are not Guarantee funds. The final sample size consists of 1,707 funds for the whole time period. Table 1 presents the aggregation of the official fund types into the new categories, including information on the sample size of each category.

Based on the per share net asset value, the management fees, and the deposit fees the before- and after-fees-monthly returns are computed for each fund. In the study we use two definitions of funds using derivatives: users and heavy users. Users are funds that have taken positions in derivatives at least once during their existence. Heavy users as funds that have taken positions in derivatives in more than $75 \%$ of the quarters of their life span and whose average notional positions are in the 75th

\footnotetext{
${ }^{9}$ The official description of each fund type is in the table 19

${ }^{10}$ In Appendix A we discuss the treatment of some conflictive observations found in the dataset.
} 
Table 1: Aggregation of Funds into Categories.

\begin{tabular}{|c|c|c|}
\hline CATEGORY & OFFICIAL CLASSIFICATION & NUMBER OF FUNDS \\
\hline \multirow[t]{3}{*}{ Balanced Domestic } & & 317 \\
\hline & RVM & 161 \\
\hline & RFM & 156 \\
\hline \multirow[t]{3}{*}{ Balanced International } & & 113 \\
\hline & RFMI & 54 \\
\hline & RVMI & 59 \\
\hline \multirow[t]{2}{*}{ Domestic Equity } & & 84 \\
\hline & RVN & 84 \\
\hline \multirow{3}{*}{ European Equity } & & 157 \\
\hline & RVE & 102 \\
\hline & RVIE & 55 \\
\hline \multirow[t]{5}{*}{ Foreign Equity } & & 261 \\
\hline & RVIJ & 23 \\
\hline & RVIO & 159 \\
\hline & RVIU & 37 \\
\hline & RVIM & 42 \\
\hline \multirow[t]{4}{*}{ Fixed Income } & & 382 \\
\hline & $\mathrm{RFCP}$ & 186 \\
\hline & RFLP & 144 \\
\hline & RFI & 52 \\
\hline \multirow{2}{*}{ Money Market } & & 211 \\
\hline & FIAMM & 211 \\
\hline \multirow[t]{2}{*}{ Global } & & 182 \\
\hline & FGL & 182 \\
\hline Total & & 1707 \\
\hline
\end{tabular}

This table reports the number of funds per official fund types and the aggregation into mutual fund categories for the analysis in this paper. The criteria used for the aggregation is the definition of each fund type, putting funds with similar definition into the same category (see appendix A). The sample covers the period from March 1995 to March 2005, and consists of those funds with at least three years of observations.Fund data is obtained from the Spanish Security and Exchange Commission, CNMV.

percentile of the whole population.

In the paper we use other non fund related data. In particular in the regression analysis we use index data to proxy for the relevant benchmark. The source of these indexes is Datastream, and the indexes used are the FTSE World Index for the global funds, the IGBM for the domestic equity funds and the balanced funds, FTSE Euroblock Index for the European funds, the Nikkei 300 for the funds investing in Japan, the MSCI Emerging Index for Emerging funds, and the S\&P500 for the US funds. 


\subsection{Descriptive Statistics}

Based on the derivative positions of each fund we construct Table 2 that provides the average numbers of some of the time series presented in Figure 1 for each fund category.

It is clear that derivative use is quite extended across fund categories. The average proportion of derivative users through time is about $40 \%$ within each fund category (see column 1 in table 2), with the exception of Money Market funds for which only an average of $19 \%$ is reported. Moreover, the amount of derivative positions is quite large. The average proportion of notional value to net asset value through categories is about $13 \%$. Money Market funds are the less aggressive funds with only a $2 \%$ average position in derivatives to total net asset value, and Domestic Equity funds the most aggressive funds with an average proportion in derivatives of almost $26 \%$ of total net asset value (see column 2 in table 2). It is also important to notice that there is an important proportion of heavy derivative users within each fund category. The average proportion of these type of funds is about $13 \%$ across fund categories. Their aggressiveness in derivative positioning is quite clear. On average they have about $40 \%$ of net asset value invested in derivative positions as measured by their notional value. European equity funds having the most aggressive heavy users of derivatives with a $62 \%$ average position in derivatives, followed by Global funds with a $58 \%$, and Domestic Equity funds with a 51\%. Finally the least aggressive fund category are the Money Market funds with a $3.6 \%$ average position in derivatives.

The CNMV requires the funds to separate their end of quarter positions into two different files, one for the derivative positions and the other for non derivative positions. Using the name or brief description available for the derivatives we classify each derivative into derivative types. ${ }^{11}$ The total number of derivatives instruments

\footnotetext{
${ }^{11}$ In order to do the classification we run a program that distinguishes some key words found in the derivative descriptions for some derivative types. The program classifies about a $98 \%$ of the derivatives, the rest is classified by hand.
} 
Table 2: Derivatives Usage by Type of Fund.

\begin{tabular}{lrrrr}
\hline \hline & \multicolumn{2}{c}{ Users of Derivatives } & \multicolumn{2}{c}{$\begin{array}{c}\text { Heavy Users of Derivatives } \\
\text { Percentage }\end{array}$} \\
Bategory & $46.6 \%$ & $11.0 \%$ & $13.6 \%$ & $28.0 \%$ \\
Balanced Domestic & $44.1 \%$ & $16.9 \%$ & $13.6 \%$ & $29.4 \%$ \\
Domestic International & $65.4 \%$ & $25.7 \%$ & $15.1 \%$ & $50.7 \%$ \\
Foreign Equity & $38.7 \%$ & $10.2 \%$ & $14.8 \%$ & $40.2 \%$ \\
Fixed Income & $44.4 \%$ & $10.6 \%$ & $14.8 \%$ & $30.5 \%$ \\
Money Market & $18.5 \%$ & $2.0 \%$ & $9.1 \%$ & $3.6 \%$ \\
Global & $45.2 \%$ & $14.9 \%$ & $11.6 \%$ & $57.8 \%$ \\
European Equity & $50.2 \%$ & $11.5 \%$ & $14.4 \%$ & $61.7 \%$ \\
\hline \hline
\end{tabular}

This table collects for each fund category the average over the sample period of he percentage of derivative users and the extent of derivative use, as measured by the total notional positions in derivatives per quarter divided by the total net asset value. The extent for heavy users is the total notional position in derivatives of heavy users divided by the total net asset value of the heavy users of derivative. The sample covers the period from March 1995 to March 2005. Fund data is obtained from the Spanish Security and Exchange Commission, CNMV. The market capitalization data is obtained from the Spanish Central Bank, Banco de España.

for the sample period form March 1995 to March 2005 is $127,603 .^{12}$ Table 3 shows the preferences for the different type of derivatives in the Spanish mutual fund industry for the 1995-2005 period. We can observe that 32.8\% of the positions correspond to option-type (non-linear) derivatives, while $48.4 \%$ are non-option type (linear) derivatives. We could not recognize $7 \%$ of the positions as any type of derivative and $10 \%$ were recognized as non derivative positions. According to the classification of the registered derivatives a greater proportion of derivatives are linear, while a smaller proportion of derivatives are non-linear. Based on the linear derivatives there is a preference for Futures, and based on the non-linear derivatives there is a preference for Calls and Floors. Warrants do not account for a great amount of derivative use. Among the non-recognized instruments most of them correspond to bond and currency related assets.

\section{Determinants and Extent of Derivative Use}

In this section we analyze the fund characteristics that are related to both the decision to use derivatives and the extent of usage. In the case of the decision to use derivatives we run a weighted least squares logit regression where the dependent vari-

\footnotetext{
${ }^{12}$ The same derivative instrument may be a position for one or more funds and for several months, but is counted as a single derivative instrument in this analysis.
} 
Table 3: Use of Derivatives by Instrument Type.

\begin{tabular}{lccc}
\hline \hline Instruments & $\mathbf{N}$ & \% of Sub totals & \% of total \\
\hline Put & 8,377 & $20 \%$ & $7 \%$ \\
Call & 14,751 & $35 \%$ & $12 \%$ \\
Floor & 13,745 & $33 \%$ & $11 \%$ \\
Cap & 1,219 & $3 \%$ & $1 \%$ \\
Warrant & 975 & $2 \%$ & $1 \%$ \\
Unknown Non Linear & 2,814 & $7 \%$ & $2 \%$ \\
& 41,881 & & \\
Forward & 11,093 & $18 \%$ & $9 \%$ \\
Future & 42,405 & $69 \%$ & $33 \%$ \\
Swap & 6,696 & $11 \%$ & $5 \%$ \\
Strips & 123 & $0 \%$ & $0 \%$ \\
Unknown Linear & 1,416 & $2 \%$ & $1 \%$ \\
& 61,733 & & \\
Unknown Derivative & 9,396 & $100 \%$ & $7 \%$ \\
Bond & & & \\
Currency & 6,754 & $54 \%$ & $5 \%$ \\
Unknown Non Derivative & 4,854 & $39 \%$ & $4 \%$ \\
& 947 & $8 \%$ & $1 \%$ \\
Unknown Instrument & 12,555 & & \\
Total & 2,034 & $100 \%$ & \\
\hline \hline
\end{tabular}

The table reports the distribution of the different derivative instruments used in the Spanish mutual fund industry. The classification is according to key words found in the description of the registered derivative instruments. A remaining small number of registered derivatives could not be classified. The sample covers the period March 1995 to March 2005. Fund data is obtained from the Spanish Security and Exchange Commission, CNMV.

able is a variable that takes the value one if the fund is a user and zero otherwise. ${ }^{13}$ In the case of the extent of usage we run a weighted least squares regression where the dependent variable is the ratio of the average notional in derivatives position to the average fund net asset value.

In both regressions, the explanatory variables are the number of funds in the family, a dummy indicating if in the family there are other funds using derivatives, the size, the age, the management fees, a dummy indicating if the fund charges frontor back-end load fees, a measure for the dividend yield, and dummies that control for fund category.

Economies of scale may play an important role in the decision and extent of

\footnotetext{
${ }^{13} \mathrm{~A}$ logit model is a more adequate model if the frequency of ones is very high, which is the case for derivative users in the sample (Greene).
} 
derivatives usage. High initial costs in equipment and regulatory requirements may prevent individual funds to use derivatives. Economies of scale considerations suggest that we should expect a greater use of derivatives when the fund belongs to a large family of funds, when there are more funds in the same family using derivatives and when the fund is large. Larger funds may also be more willing to use derivatives in order to manage their large positions more efficiently. The age of the fund may also play a role on the choice to use derivatives. On the one hand if young funds are associated with young managers, it could be that young managers are more willing to use sophisticated financial instruments. On the other hand, older funds may be managed by well experienced professionals who in turn are allowed to use derivatives.

Skillful managers may have a preference for derivatives. Since these managers are relatively better paid, larger fees are expected to be associated to larger derivatives usage. Load fees may be used to control for investor redemptions and deposits. The larger the load the smaller the cash inflows and outflows. If derivatives are used to manage cash flows then funds that charge no loads are more likely to use derivatives. Finally, the dividend yield may proxy the fund's investment style, associating higher dividend yield with value funds. Growth oriented funds may be more likely to use derivatives in order to capture the growth of stocks more efficiently.

\subsection{Determinants of the decision to use derivatives}

To analyze the decision to use derivatives we consider the following logit model:

$$
\begin{aligned}
\text { der }_{i}= & \alpha+\beta_{1} \text { numfunds }_{i}+\beta_{2} \text { moreuser }_{i}+\beta_{3} \text { lognav }_{i}+\beta_{4} \text { assetfee }_{i} \\
& +\beta_{5} \text { inception }_{i}+\beta_{6} \text { noload }_{i}+\beta_{7} \text { divyield }_{i}+\sum_{j} \beta_{j} \text { dummy }_{j, i}+\epsilon_{i}
\end{aligned}
$$

where $d e r_{i}$ is a zero-one variable indicating derivative use by fund $i$, numfunds $s_{i}$ is the number of funds in the family, moreusers $s_{i}$ is the dummy indicating if there is another fund in the family using derivatives, $\operatorname{lognav}_{i}$ is the log of the net asset value, 
assetfee $_{i}$ is the management fee, inception $_{i}$ is the year of inception, noload $_{i}$ is the dummy indicating if the fund charges no loads, divyield $d_{i}$ is a measure for the dividend yield, and the rest of dummies control for fund category.

\section{Table 4: Determinants of the Decision and Extent of Derivatives Usage.}

\begin{tabular}{lcc}
\hline \hline & Decision & Extent \\
\cline { 2 - 3 } Number of funds in family & 0.0006 & 0.001 \\
More users of derivatives in family & $(0)^{* * *}$ & $(0.000)^{* * *}$ \\
& $(0.1399$ & 0.096 \\
Log of net asset value & 0.0155 & $(0.057)^{* *}$ \\
Management fee & $(0.005)^{* * *}$ & $(0.001$ \\
& 0.0624 & $0.093)$ \\
Inception year & $(0.025)^{* *}$ & $(0.039)^{* *}$ \\
& -0.0010 & 0.005 \\
No load & $(0.002)$ & $(0.003)^{* *}$ \\
& 0.0336 & -0.013 \\
Dividend yield & $(0.012)^{* * *}$ & $(0.017)$ \\
& -0.2253 & -0.193 \\
Constant & $(0.1)^{* *}$ & $(0.153)$ \\
Observations & 1.7397 & \\
Degrees of freedom & & 1129 \\
Log Likelihood & 14 & \\
Pseudo r2 & -299.51 & \\
\hline \hline
\end{tabular}

This table reports a weighted logit for the Determinants regression and a weighted least squares for the Extent regression. The weights are one divided by the square root of the number of observations used to compute the averages of the fund characteristics. The dependent variable, in the Determinants regression, is a zero-one variable indicating derivative use. In the Extent regression the dependent variable is the open Notional position in derivatives to total net asset value. Marginal effects of fund characteristics evaluated at average values are the coefficients in the Determinants regression and Extent of Derivative Use. The fund categories are the control variables. The sample covers the period from March 1995 to March 2005, and consists of those funds with at least three years of observations.Fund data is obtained from the Spanish Security and Exchange Commission, CNMV. Standard errors are in parentheses. * significant at $10 \%$; ** significant at $5 \%$; *** significant at $1 \%$.

The first column in Table 4 reports the results obtained in the logit model (1). First notice that we find that the probability of using derivatives increases with the number of funds in the family, the existence of other users in the family and with the size of the fund. These three first results highlight the key role of economies of scales in the decision to use derivatives. The significance of size also supports the idea that larger funds are more willing to use derivatives to manage their positions. Larger management fees also have a positive effect on the probability of using derivatives, probably indicating that more skillful managers are better paid and are more 
likely to use derivatives. Higher skilled managers are more likely to use derivatives. Charging no loads increases by $2.5 \%$ the probability of using derivatives indicating the possibility of derivatives being used for cash flow management purposes. This hypothesis is corroborated in section 7 using a different methodology. The results also show that low dividend yields are related to derivative use, indicating the use of derivatives by growth oriented funds. The only variable that does not affect the decision to use derivatives is the fund's age.

To sum up, at the fund level, having more funds in the family, having other funds in the family using derivatives, having larger assets, charging larger fees on total assets, charging no loads and having a lower dividend yield increases the probability of using derivatives.

\subsection{Extent of derivatives usage}

In this case we run a weighted least squares regression of equation (1) defining $d e r_{i}$ as the extent of usage rather than the binary variable for the decision to use derivatives. This variable is the average position in derivatives divided by the average fund net asset value for the 1995-2005 period. The results obtained in the estimation are reported in the second column of Table 4. Again, economies of scale play a significant role. The only variable related to economies of scales that loses significance is the fund's size. Management fees again are positively related to usage. Unlike in the case of the decision to use derivatives, the fund's age is significant. That is, younger funds are more aggressive in their position taking in derivatives.

Two main conclusions can be drawn from the exercise in this section. First, the main characteristics associated to the decision to use derivatives and the extent of its use are those related to economies of scale and fees. Users are more likely to be funds that belong to a large family of funds in which other funds also use derivatives. Furthermore, users are more likely to be expensive funds. This last result motivates our decision to consider fund returns both before and after fees in the empirical study 
that follows. The other main conclusion is that there is evidence of users being funds that do not penalize cash inflows and outflows. This already hints at users as funds that may be using derivatives to manage these cashflows. In section ?? we retake this issue and provide extra evidence in support of this conjecture.

\section{Derivatives Usage and Performance}

\subsection{Fund Risk and Performance in the Context of the Market Model}

In this section we study the performance of users versus non users of derivatives, in each of the fund categories, using performance measures that arise in the basic mean variance/CAPM framework. In particular we compare how well the group of users versus non-users perform in term of Sharpe ratios, Jensen's alphas, appraisal ratios, and the Treynor index. The Sharpe ratio is the fund's excess return above the risk free rate divided by the standard deviation. It is the appropriate performance measure from the point of view of no well diversified investors or investors who are heavily invested in the fund. Positive Sharpe ratios and above the Sharpe ratio of the market portfolio constitute evidence of superior performance. The Jensen's alpha corresponds to the alpha of the market model. It is the measure of performance of interest for well diversified investors. A positive alpha is evidence of superior performance. The appraisal ratio is defined as the Jensen's alpha divided by the root mean squared error of the market model. It is a measure of interest for well diversified investors. The larger the appraisal ratio, the better the performance. Finally, the Treynor index is similar to the Sharpe ratio, only that the adjustment is made according to the fund's exposure to the market (beta) rather than the total risk. It indicates if the fund outperforms the risk free rate and if the performance is achieved with lower market 
exposure $^{14}$.

The market model is given by:

$$
r_{i, t}-r_{f, t}=\alpha_{i}+\beta_{i} *\left(r_{m, t}-r_{f, t}\right)+\varepsilon_{i, t}
$$

where $r_{i, t}$ is the fund's return, $r_{f, t}$ is the risk free rate, and $r_{m, t}$ is the market's return. The appropriate market portfolio is selected according to the official fund type. For the Balanced Domestic and Domestic Equity funds the Spanish market index, IGBM, is used. For the European Equity and Foreign Equity funds the corresponding market index is selected, ranging form the FTSE Euro Block Index, FTSE World index, the Medium Term and Long Term Index ${ }^{15}$ the Nikkei 300, the MSCI Emerging Index, and the S\&P500. For the Money Market funds and Short Term Fixed Income Funds the return on the market are the Spanish treasury bills and the risk-free rate is the one week repo rate. For all other funds the risk-free rate is the Spanish one month treasury bill $^{16}$. The sources of the information are Datastream and the Spanish Central bank.

We first estimate the market model for the whole universe of funds. Then we separate users from non users and group each one of them in their corresponding category. We test for differences in the means of the coefficients for users versus non users using the t-statistic. To test for differences in the median we use the Wilcoxon test. Table 5 reports the results. The table also includes information of the betas and the idiosyncratic risk estimated using the market model. First, in sharp contrast to the results obtained in Koski and Pontiff (1999) for the US market, in the Spanish case there are only three fund categories for which fund users are not distinguished from non users: Balance Domestic, Foreign Equity and Money Market. Furthermore, in the case of Money Market funds the result is expected since by regulation Money

\footnotetext{
${ }^{14}$ For a deeper discussion on these performance measures and results obtained in the Spanish market, for instance see Marin and Rubio (2001).

${ }^{15}$ This Medium and Long Term Index is constructed by the Spanish Central Bank, Banco de España.

${ }^{16}$ The treasury bills are known as "Letras del Tesoro" in Spanish.
} 
Market funds are only allowed to use derivatives to reduce risk. More striking even is that we only find one category where there is some (very weak) evidence of a better performance by users: Fixed income. In particular, users exhibit a larger appraisal ratio, but also a smaller Sharpe ratio than non users. In the remaining four categories users perform worst than non-users, in the sense of exhibiting bad news in at least one performance evaluation measure.

Table 5: Risk and Performance of Users in a Market Model Context.

\begin{tabular}{|c|c|c|c|c|c|c|c|}
\hline \multirow[t]{2}{*}{ Category } & \multirow[t]{2}{*}{ measure } & \multicolumn{2}{|c|}{ non-users } & \multicolumn{2}{|c|}{ users } & \multirow{2}{*}{$\begin{array}{l}\text { ttest } \\
\text { t-stat }\end{array}$} & \multirow{2}{*}{$\begin{array}{c}\text { Wilcoxon } \\
\text { z-stat }\end{array}$} \\
\hline & & $\mathbf{N}$ & mean & $\mathbf{N}$ & mean & & \\
\hline \multirow{6}{*}{ Balanced Domestic } & Beta & 35 & 0.3792 & 282 & 0.3197 & 1.65 & 1.6 \\
\hline & Idiosyncratic risk & 35 & 0.0110 & 282 & 0.0104 & 0.53 & 0.78 \\
\hline & Jensen's alpha & 35 & -0.0018 & 282 & -0.0018 & 0.03 & -0.08 \\
\hline & Appraisal Ratio & 35 & -0.1715 & 282 & -0.1855 & 0.47 & -0.15 \\
\hline & Sharpe Ratio & 35 & -0.0458 & 282 & -0.0191 & -1.33 & -1.29 \\
\hline & Treynor Index & 35 & -0.0021 & 282 & -0.0037 & 0.33 & -0.93 \\
\hline \multirow{6}{*}{ Balanced International } & Beta & 20 & 0.4106 & 93 & 0.3127 & $1.9^{*}$ & $2.17^{* *}$ \\
\hline & Idiosyncratic risk & 20 & 0.0099 & 93 & 0.0114 & -0.82 & -0.8 \\
\hline & Jensen's alpha & 20 & 0.0003 & 93 & -0.0007 & $2.64^{* * *}$ & $2.8^{* * *}$ \\
\hline & Appraisal Ratio & 20 & 0.0193 & 93 & -0.0905 & $3.08^{* * *}$ & $2.68^{* * *}$ \\
\hline & Sharpe Ratio & 20 & -0.0926 & 93 & -0.0842 & -0.3 & -0.31 \\
\hline & Treynor Index & 20 & -0.0051 & 93 & -0.0145 & 0.68 & 0.5 \\
\hline \multirow[t]{6}{*}{ Domestic Equity } & Beta & 6 & 0.8155 & 78 & 0.8870 & -0.78 & $-1.77^{*}$ \\
\hline & Idiosyncratic risk & 6 & 0.0117 & 78 & 0.0140 & -0.83 & -1.09 \\
\hline & Jensen's alpha & 6 & 0.0014 & 78 & -0.0010 & $1.93^{*}$ & $2.29^{* *}$ \\
\hline & Appraisal Ratio & 6 & 0.1347 & 78 & -0.0908 & $2.55^{* *}$ & $2.33^{* *}$ \\
\hline & Sharpe Ratio & 6 & 0.1186 & 78 & 0.0820 & 1.21 & 0.61 \\
\hline & Treynor Index & 6 & 0.0067 & 78 & 0.0055 & 0.57 & 0.45 \\
\hline \multirow[t]{6}{*}{ European Equity } & Beta & 30 & 0.8620 & 127 & 0.9504 & $-1.82^{*}$ & $-2.33^{* *}$ \\
\hline & Idiosyncratic risk & 30 & 0.0251 & 127 & 0.0208 & $2.56^{* *}$ & $2.76^{* * *}$ \\
\hline & Jensen's alpha & 30 & 0.0023 & 127 & -0.0003 & $3.64^{* * *}$ & $2.68^{* * *}$ \\
\hline & Appraisal Ratio & 30 & 0.0679 & 127 & -0.0349 & $3.06^{* * *}$ & $2.41^{* *}$ \\
\hline & Sharpe Ratio & 30 & 0.0122 & 127 & -0.0267 & $1.88^{*}$ & 0.85 \\
\hline & Treynor Index & 30 & 0.0020 & 127 & -0.0006 & 1.38 & 0.81 \\
\hline \multirow[t]{6}{*}{ Fixed Income } & Beta & 34 & 1.0967 & 348 & 0.6753 & $2.61^{* * *}$ & $2.19^{* *}$ \\
\hline & Idiosyncratic risk & 34 & 0.0031 & 348 & 0.0056 & $-2.35^{* *}$ & $-4.09 * * *$ \\
\hline & Jensen's alpha & 34 & -0.0009 & 348 & -0.0005 & -1.45 & -1.31 \\
\hline & Appraisal Ratio & 34 & -0.5831 & 348 & -0.1645 & $-4.17^{* * *}$ & $-3.6 * * *$ \\
\hline & Sharpe Ratio & 34 & 1.2114 & 348 & 0.5786 & $4.4^{* * *}$ & $3.86^{* * *}$ \\
\hline & Treynor Index & 34 & 0.0023 & 348 & 0.0005 & 0.52 & -0.15 \\
\hline
\end{tabular}


Table 5 - Continued from previous page

\begin{tabular}{|c|c|c|c|c|c|c|c|}
\hline \multirow[t]{2}{*}{ Category } & \multirow[t]{2}{*}{ measure } & \multicolumn{2}{|c|}{ non-users } & \multicolumn{2}{|c|}{ users } & \multirow{2}{*}{$\begin{array}{c}\text { ttest } \\
\text { t-stat }\end{array}$} & \multirow{2}{*}{$\begin{array}{c}\text { Wilcoxon } \\
\text { z-stat }\end{array}$} \\
\hline & & $\mathbf{N}$ & mean & $\mathbf{N}$ & mean & & \\
\hline \multirow[t]{6}{*}{ Foreign Equity } & Beta & 49 & 0.8943 & 211 & 0.8848 & 0.22 & 0.45 \\
\hline & Idiosyncratic risk & 49 & 0.0236 & 211 & 0.0278 & $-2.1^{* *}$ & $-1.75^{*}$ \\
\hline & Jensen's alpha & 49 & -0.0002 & 211 & -0.0011 & 1.25 & 1.18 \\
\hline & Appraisal Ratio & 49 & -0.0315 & 211 & -0.0504 & 0.72 & 0.85 \\
\hline & Sharpe Ratio & 49 & -0.0698 & 211 & -0.0783 & 0.53 & 0.3 \\
\hline & Treynor Index & 49 & -0.0041 & 211 & -0.0044 & 0.26 & 0.45 \\
\hline \multirow[t]{6}{*}{ Money Market } & Beta & 51 & 0.9599 & 159 & 0.8932 & 0.88 & -0.32 \\
\hline & Idiosyncratic risk & 51 & 0.0011 & 159 & 0.0009 & 0.43 & -1.4 \\
\hline & Jensen's alpha & 51 & -0.0006 & 159 & -0.0003 & -0.71 & -0.27 \\
\hline & Appraisal Ratio & 51 & -1.1404 & 159 & -0.9858 & -1.21 & -0.59 \\
\hline & Sharpe Ratio & 51 & 1.6417 & 159 & 1.5402 & 1.33 & 1.45 \\
\hline & Treynor Index & 51 & 0.0017 & 159 & 0.0026 & -1.52 & 0.1 \\
\hline \multirow[t]{6}{*}{ Global } & Beta & 17 & 0.3655 & 165 & 0.3357 & 0.4 & 0.14 \\
\hline & Idiosyncratic risk & 17 & 0.0122 & 165 & 0.0172 & -1.46 & -1.57 \\
\hline & Jensen's alpha & 17 & 0.0004 & 165 & -0.0010 & 1.61 & $2.38^{* *}$ \\
\hline & Appraisal Ratio & 17 & -0.0405 & 165 & -0.0596 & 0.47 & $1.72^{*}$ \\
\hline & Sharpe Ratio & 17 & -0.1060 & 165 & -0.0680 & -1.06 & -0.24 \\
\hline & Treynor Index & 17 & -0.0333 & 165 & 0.0030 & -0.56 & -0.22 \\
\hline
\end{tabular}

This table presents the results for different risk and performance measures per fund category and group: users and nonusers of derivatives. A t-test and a Wilcoxon test are performed on the mean and median group values, respectively. The measures are the appraisal ratio, the beta of a market model, the Jensen's alpha form a market model, the idiosyncratic risk measured by the root mean squared error of the CNMV.* significant at $10 \%$;** significant at $5 \% ; * * *$ significant at $1 \%$

It is possible that the very negative picture that arises from Table 5 is due to our definition of users. In particular, we may be including as users funds that have used derivatives very rarely and with bad luck in the past. For this reason we repeat the previous exercise but using the definition of heavy users. In this case we are looking at the performance of funds that not only use derivatives frequently but also take positions whose notional is relatively large.

In Table 6 we report the results for heavy users. In general the results do not improve significantly. But there is some new evidence which is worthwhile addressing. First, Fixed Income remains as the only category in which there is some evidence of outperformance. The evidence is still very weak as only the appraisal ratio remains significantly larger. The second observation is that we now find some evidence of improved and worsening in performance in some of the other categories. In particular 
the performance of users in the Foreign Equity worsens (before there were no differences and now they exhibit worst performance) and the performance in European Equity funds improve (moving from underperformance to no significant differences).

In the rest of categories the results are as negative or worst than before.

Table 6: Risk and Performance of Heavy Users in a Market Model Context.

\begin{tabular}{|c|c|c|c|c|c|c|c|}
\hline \multirow{2}{*}{ 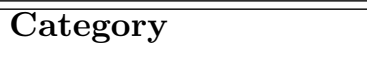 } & \multirow[t]{2}{*}{ measure } & \multicolumn{2}{|c|}{ non-users } & \multicolumn{2}{|c|}{ heavy users } & \multirow{2}{*}{$\begin{array}{l}\text { ttest } \\
\text { t-stat }\end{array}$} & \multirow{2}{*}{$\begin{array}{c}\text { Wilcoxon } \\
\text { z-stat }\end{array}$} \\
\hline & & $\mathbf{N}$ & mean & $\mathbf{N}$ & mean & & \\
\hline \multirow{6}{*}{ Balanced Domestic } & Beta & 35 & 0.3792 & 50 & 0.3429 & 0.8 & 0.74 \\
\hline & Idiosyncratic Risk & 35 & 0.0110 & 50 & 0.0105 & 0.39 & 0.6 \\
\hline & Jensen's alpha & 35 & -0.0018 & 50 & -0.0018 & 0.07 & 0.14 \\
\hline & Appraisal Ratio & 35 & -0.1715 & 50 & -0.1915 & 0.57 & -0.03 \\
\hline & Sharpe Ratio & 35 & -0.0458 & 50 & -0.0227 & -0.84 & -0.91 \\
\hline & Treynor Index & 35 & -0.0021 & 50 & -0.0015 & -0.3 & -0.75 \\
\hline \multirow[t]{6}{*}{ Balanced International } & Beta & 20 & 0.4106 & 17 & 0.3141 & 1.67 & $1.77^{*}$ \\
\hline & Idiosyncratic Risk & 20 & 0.0099 & 17 & 0.0124 & -0.88 & -0.76 \\
\hline & Jensen's alpha & 20 & 0.0003 & 17 & -0.0009 & $2.8^{* * *}$ & $2.62^{* * *}$ \\
\hline & Appraisal Ratio & 20 & 0.0193 & 17 & -0.0976 & $2.71^{* *}$ & $2.29^{* *}$ \\
\hline & Sharpe Ratio & 20 & -0.0926 & 17 & -0.0868 & -0.2 & 0.03 \\
\hline & Treynor Index & 20 & -0.0051 & 17 & -0.0051 & 0.04 & 0.49 \\
\hline \multirow[t]{6}{*}{ Domestic Equity } & Beta & 6 & 0.8155 & 15 & 1.0250 & $-5.57 * * *$ & $-3.43^{* * *}$ \\
\hline & Idiosyncratic Risk & 6 & 0.0117 & 15 & 0.0109 & 0.48 & 0.47 \\
\hline & Jensen's alpha & 6 & 0.0014 & 15 & -0.0013 & $2.57^{* *}$ & $1.95^{*}$ \\
\hline & Appraisal Ratio & 6 & 0.1347 & 15 & -0.1253 & $2.67^{* *}$ & $2.02^{* *}$ \\
\hline & Sharpe Ratio & 6 & 0.1186 & 15 & 0.0602 & 1.67 & 1.09 \\
\hline & Treynor Index & 6 & 0.0067 & 15 & 0.0037 & 1.53 & 1.01 \\
\hline \multirow[t]{6}{*}{ European Equity } & Beta & 30 & 0.8620 & 28 & 1.0137 & $-2.69 * * *$ & $-3.1^{* * *}$ \\
\hline & Idiosyncratic Risk & 30 & 0.0251 & 28 & 0.0202 & $2.34^{* *}$ & $2.35^{* *}$ \\
\hline & Jensen's alpha & 30 & 0.0023 & 28 & 0.0009 & 1.21 & 0.87 \\
\hline & Appraisal Ratio & 30 & 0.0679 & 28 & 0.0326 & 0.73 & 0.36 \\
\hline & Sharpe Ratio & 30 & 0.0122 & 28 & -0.0380 & 1.56 & 1.03 \\
\hline & Treynor Index & 30 & 0.0020 & 28 & -0.0020 & 1.66 & 1.04 \\
\hline \multirow[t]{6}{*}{ Fixed Income } & Beta & 34 & 1.0967 & 71 & 0.6421 & $1.91^{*}$ & $2.16^{* *}$ \\
\hline & Idiosyncratic Risk & 34 & 0.0031 & 71 & 0.0076 & $-3.49^{* * *}$ & $-5.07 * * *$ \\
\hline & Jensen's alpha & 34 & -0.0009 & 71 & -0.0004 & -1.1 & -1.38 \\
\hline & Appraisal Ratio & 34 & -0.5831 & 71 & -0.1059 & $-3.76^{* * *}$ & $-3.78^{* * *}$ \\
\hline & Sharpe Ratio & 34 & 1.2114 & 71 & 0.3105 & $6.74^{* * *}$ & $4.43^{* * *}$ \\
\hline & Treynor Index & 34 & 0.0023 & 71 & 0.0032 & -0.31 & 1.19 \\
\hline \multirow[t]{4}{*}{ Foreign Equity } & Beta & 49 & 0.8943 & 49 & 0.8991 & -0.11 & 0.47 \\
\hline & Idiosyncratic Risk & 49 & 0.0236 & 49 & 0.0289 & $-1.97^{*}$ & -1.35 \\
\hline & Jensen's alpha & 49 & -0.0002 & 49 & -0.0009 & 0.83 & 0.41 \\
\hline & & & & & & \multicolumn{2}{|c|}{ Continued on next page } \\
\hline
\end{tabular}


Table 6 - Continued from previous page

\begin{tabular}{|c|c|c|c|c|c|c|c|}
\hline \multirow[t]{2}{*}{ Category } & \multirow[t]{2}{*}{ measure } & \multicolumn{2}{|c|}{ non-users } & \multicolumn{2}{|c|}{ heavy users } & \multirow{2}{*}{$\begin{array}{c}\text { ttest } \\
\text { t-stat }\end{array}$} & \multirow{2}{*}{$\begin{array}{c}\text { Wilcoxon } \\
\text { z-stat } \\
\end{array}$} \\
\hline & & $\mathbf{N}$ & mean & $\mathbf{N}$ & mean & & \\
\hline & Appraisal Ratio & 49 & -0.0315 & 49 & -0.0370 & 0.15 & -0.07 \\
\hline & Sharpe Ratio & 49 & -0.0698 & 49 & -0.1035 & $1.72^{*}$ & $1.74^{*}$ \\
\hline & Treynor Index & 49 & -0.0041 & 49 & -0.0067 & $2.11^{* *}$ & $2.03^{* *}$ \\
\hline \multirow[t]{6}{*}{ Money Market } & Beta & 51 & 0.9599 & 40 & 0.9568 & 0.06 & -1.16 \\
\hline & Idiosyncratic Risk & 51 & 0.0011 & 40 & 0.0008 & 0.89 & $-2.29 * *$ \\
\hline & Jensen's alpha & 51 & -0.0006 & 40 & -0.0006 & 0.08 & -0.22 \\
\hline & Appraisal Ratio & 51 & -1.1404 & 40 & -0.8582 & -1.54 & -1.03 \\
\hline & Sharpe Ratio & 51 & 1.6417 & 40 & 1.5350 & 1.02 & 1.03 \\
\hline & Treynor Index & 51 & 0.0017 & 40 & 0.0027 & -0.91 & -1.18 \\
\hline \multirow[t]{6}{*}{ Global } & Beta & 17 & 0.3655 & 27 & 0.3395 & 0.25 & -0.11 \\
\hline & Idiosyncratic Risk & 17 & 0.0122 & 27 & 0.0188 & -1.2 & -1.1 \\
\hline & Jensen's alpha & 17 & 0.0004 & 27 & -0.0020 & 1.56 & $2.16^{* *}$ \\
\hline & Appraisal Ratio & 17 & -0.0405 & 27 & -0.0700 & 0.51 & $1.77^{*}$ \\
\hline & Sharpe Ratio & 17 & -0.1060 & 27 & -0.0831 & -0.42 & 0.3 \\
\hline & Treynor Index & 17 & -0.0333 & 27 & -0.0516 & 0.48 & 0.4 \\
\hline
\end{tabular}

The table presents the results for different risk and performance measures per fund category and group: heavy users and non users of derivatives. Funds are defined as heavy users if their frequency of derivative use is larger than the 75 percentile and their average ratio of notional value in derivatives to net asset value is larger than the 75 percentile. A t-test and a Wilcoxon test are performed on the mean and median group values, respectively. The measures are the appraisal ratio, the beta of a market model, the Jensen's alpha form a market model, the idiosyncratic risk measured by the root mean squared error of the market model, the Sharpe ratio, and the Treynor index. Computations are based on monthy returns and the management fee and the deposit fees are added back. The sample covers the Spanish Security an the Spanish Security and Exchange Commission, CNMV. * significant at 10\%; ** significant at $5 \%$; *** significant at $1 \%$.

In Section 4 we provided evidence of fund users being relatively expensive funds. It may be the case that the poor performance of users identified in the previous two exercises is due to the large expenses these funds must satisfy. To verify this we repeat our performance analysis but using the fund returns before fees rather than after fees as we did before. Results are reported in Tables 7 and 8. In general the results improve a little bit in the case of users but not in the case of heavy users. In particular, we find improvements in two categories: Money Market funds (in terms of the appraisal ratio) and Foreign Equity (in terms of Jensen's alpha). On the other hand, the only category exhibiting some signs of superior performance after fees, Fixed Income, stops exhibiting superior performance in terms of the appraisal ratio, but now exhibits superior performance in terms of Jensen's alpha. However, there are no further improvements when we look at heavy users. In this case the three previous categories (Fixed Income, Money Market and Foreign Equity) remain exhibiting 
superior performance, but the rest of categories exhibit now worst performance ${ }^{17}$.

Table 7: Risk and Performance Before Fees of Users in a Market Model Context.

\begin{tabular}{|c|c|c|c|c|c|c|c|}
\hline \multirow[t]{2}{*}{ Category } & \multirow[t]{2}{*}{ measure } & \multicolumn{2}{|c|}{ non-users } & \multicolumn{2}{|c|}{ users } & \multirow{2}{*}{$\begin{array}{l}\text { ttest } \\
\text { t-stat }\end{array}$} & \multirow{2}{*}{$\begin{array}{c}\text { Wilcoxon } \\
\text { z-stat }\end{array}$} \\
\hline & & $\mathbf{N}$ & mean & $\mathbf{N}$ & mean & & \\
\hline \multirow{6}{*}{ Balanced Domestic } & Beta & 35 & 0.3785 & 282 & 0.3198 & 1.62 & 1.57 \\
\hline & Idiosyncratic Risk & 35 & -0.0006 & 282 & -0.0004 & -0.76 & -0.8 \\
\hline & Jensen's alpha & 35 & 0.0110 & 282 & 0.0104 & 0.52 & 0.75 \\
\hline & Appraisal Ratio & 35 & -0.0495 & 282 & -0.0008 & $-1.67^{*}$ & $-1.56^{* * *}$ \\
\hline & Sharpe Ratio & 35 & 0.0136 & 282 & 0.0717 & $-3.11^{* * *}$ & -2.32 \\
\hline & Treynor Index & 35 & 0.0024 & 282 & 0.0067 & -1.61 & -2.29 \\
\hline \multirow[t]{6}{*}{ Balanced International } & Beta & 20 & 0.4108 & 93 & 0.3127 & $1.9^{*}$ & $2.18^{* *}$ \\
\hline & Idiosyncratic Risk & 20 & 0.0017 & 93 & 0.0006 & $2.98^{* * *}$ & $2.93^{* * *}$ \\
\hline & Jensen's alpha & 20 & 0.0099 & 93 & 0.0114 & -0.83 & -0.85 \\
\hline & Appraisal Ratio & 20 & 0.1987 & 93 & 0.0624 & $4.19^{* * *}$ & $3.43^{*}$ \\
\hline & Sharpe Ratio & 20 & -0.0218 & 93 & 0.0104 & -1.28 & -1.11 \\
\hline & Treynor Index & 20 & -0.0011 & 93 & -0.0048 & 0.31 & -0.8 \\
\hline \multirow[t]{6}{*}{ Domestic Equity } & Beta & 6 & 0.8148 & 78 & 0.8871 & -0.78 & $-1.77^{*}$ \\
\hline & Idiosyncratic Risk & 6 & 0.0028 & 78 & 0.0006 & $1.83^{*}$ & $1.91^{*}$ \\
\hline & Jensen's alpha & 6 & 0.0117 & 78 & 0.0140 & -0.83 & -1.11 \\
\hline & Appraisal Ratio & 6 & 0.2668 & 78 & 0.0413 & $2.79 * * *$ & $2.36^{* * *}$ \\
\hline & Sharpe Ratio & 6 & 0.1492 & 78 & 0.1137 & 1.14 & $0.57^{* *}$ \\
\hline & Treynor Index & 6 & 0.0085 & 78 & 0.0076 & 0.31 & 0.28 \\
\hline \multirow[t]{6}{*}{ European Equity } & Beta & 30 & 0.8620 & 127 & 0.9506 & $-1.83^{*}$ & $-2.34^{* *}$ \\
\hline & Idiosyncratic Risk & 30 & 0.0038 & 127 & 0.0013 & $3.51^{* * *}$ & $2.53^{* *}$ \\
\hline & Jensen's alpha & 30 & 0.0251 & 127 & 0.0208 & $2.56^{* *}$ & $2.76^{* * *}$ \\
\hline & Appraisal Ratio & 30 & 0.1341 & 127 & 0.0532 & $2.62^{* * *}$ & $1.92^{* * *}$ \\
\hline & Sharpe Ratio & 30 & 0.0413 & 127 & 0.0054 & $1.71^{*}$ & $0.7^{* *}$ \\
\hline & Treynor Index & 30 & 0.0038 & 127 & 0.0024 & 0.39 & 0.71 \\
\hline \multirow[t]{6}{*}{ Fixed Income } & Beta & 34 & -0.4950 & 348 & -0.2567 & -0.57 & -1.15 \\
\hline & Idiosyncratic Risk & 34 & -0.0002 & 348 & 0.0007 & $-3.19^{* * *}$ & $-4.89 * * *$ \\
\hline & Jensen's alpha & 34 & 0.0031 & 348 & 0.0056 & $-2.36^{* *}$ & $-4.1^{* * *}$ \\
\hline & Appraisal Ratio & 34 & 0.2882 & 348 & 0.2602 & 0.32 & 0.19 \\
\hline & Sharpe Ratio & 34 & 1.7206 & 348 & 0.8769 & $5.01^{* * *}$ & $3.93^{* *}$ \\
\hline & Treynor Index & 34 & 0.0029 & 348 & 0.0052 & -0.47 & -2.06 \\
\hline \multirow[t]{4}{*}{ Foreign Equity } & Beta & 49 & 0.8944 & 211 & 0.8849 & 0.22 & 0.45 \\
\hline & Idiosyncratic Risk & 49 & 0.0014 & 211 & 0.0005 & 1.26 & 1.15 \\
\hline & Jensen's alpha & 49 & 0.0236 & 211 & 0.0278 & $-2.1^{* *}$ & $-1.74^{*}$ \\
\hline & Appraisal Ratio & 49 & 0.0456 & 211 & 0.0189 & 1.09 & 1.23 \\
\hline
\end{tabular}

\footnotetext{
${ }^{17}$ The exception is the Balance Domestic category in which there are no significant differences in performance in any of the four exercises we execute.
} 
Table 7 - Continued from previous page

\begin{tabular}{|c|c|c|c|c|c|c|c|}
\hline \multirow[t]{2}{*}{ Category } & \multirow[t]{2}{*}{ measure } & \multicolumn{2}{|c|}{ non-users } & \multicolumn{2}{|c|}{ users } & \multirow{2}{*}{$\begin{array}{l}\text { ttest } \\
\text { t-stat }\end{array}$} & \multirow{2}{*}{$\begin{array}{c}\text { Wilcoxon } \\
\text { z-stat }\end{array}$} \\
\hline & & $\mathbf{N}$ & mean & $\mathbf{N}$ & mean & & \\
\hline & Sharpe Ratio & 49 & -0.0414 & 211 & -0.0475 & 0.37 & 0.33 \\
\hline & Treynor Index & 49 & -0.0023 & 211 & -0.0029 & 0.48 & 0.58 \\
\hline \multirow[t]{6}{*}{ Money Market } & Beta & 51 & -0.0320 & 159 & 0.0089 & -0.26 & 1.37 \\
\hline & Idiosyncratic Risk & 51 & 0.0002 & 159 & 0.0002 & -0.09 & $-3.23^{* * *}$ \\
\hline & Jensen's alpha & 51 & 0.0011 & 159 & 0.0009 & 0.4 & -1.19 \\
\hline & Appraisal Ratio & 51 & 0.5036 & 159 & 0.5305 & -0.33 & $-1.26^{*}$ \\
\hline & Sharpe Ratio & 51 & 2.2178 & 159 & 2.1264 & 0.97 & 0.88 \\
\hline & Treynor Index & 51 & -0.0090 & 159 & 0.0034 & $-1.76^{*}$ & -0.53 \\
\hline \multirow[t]{6}{*}{ Global } & Beta & 17 & 0.3656 & 165 & 0.3359 & 0.4 & 0.14 \\
\hline & Idiosyncratic Risk & 17 & 0.0016 & 165 & 0.0002 & $1.74^{*}$ & $2.33^{* *}$ \\
\hline & Jensen's alpha & 17 & 0.0122 & 165 & 0.0172 & -1.46 & -1.56 \\
\hline & Appraisal Ratio & 17 & 0.1578 & 165 & 0.0524 & $2.64^{* * *}$ & $2.53 * * *$ \\
\hline & Sharpe Ratio & 17 & 0.0509 & 165 & 0.0163 & 0.92 & $0.23^{* * *}$ \\
\hline & Treynor Index & 17 & -0.0002 & 165 & 0.0719 & -0.43 & -0.72 \\
\hline
\end{tabular}

The table presents the results for different risk and performance measures per fund category and group: users and nonusers of derivatives. A t-test and a Wilcoxon test are performed on the mean and median group values, respectively. The measures are the appraisal ratio, the beta of a market model, the Jensen's alpha form a market model, the idiosyncratic risk measured by the root mean squared error of the market model, the Sharpe ratio, and the Treynor index. Computations are based on monthly returns and the management fee and the deposit fees are added back. The sample covers the period from March 1995 to March 2005 and funds with more than three years of monthly observations. Fund data is obtained from the Spanish Security and Exchange Commission, CNMV. * significant at $10 \%$; ** significant at $5 \% ; * * *$ significant at $1 \%$.

Two big conclusions can be drawn from these last two exercises. First, it turns out that charging large expenses is one of the variables behind the poor performance of mutual funds using derivatives. This variable, however, only provides a partial explanation as it does not account for the underperformance in all categories. Second, contrary to what we expected, heavy usage is not associated to improvements in performance. Heave usage is a (probably noisy) proxy for expertise in derivative usage. It is rather paradoxical that more experienced derivative traders do not exhibit superior performance.

Table 8: Risk and Performance Before Fees of Heavy Users in a Market Model Context.

\begin{tabular}{llcccccc}
\hline Category & measure & \multicolumn{2}{c}{ non-users } & \multicolumn{2}{c}{ heavy users } & ttest & Wilcoxon \\
& & N & mean & N & mean & t-stat & z-stat \\
\hline Balanced Domestic & Beta & 35 & 0.3785 & 282 & 0.3198 & 1.62 & 1.57 \\
& Idiosyncratic Risk & 35 & -0.0006 & 282 & -0.0004 & -0.76 & -0.8 \\
& Jensen's alpha & 35 & 0.0110 & 282 & 0.0104 & 0.52 & 0.75 \\
& & & & & & & \\
& Appraisal Ratio & 35 & -0.0495 & 282 & -0.0008 & $-1.67^{*}$ & $-1.56^{* * *}$ \\
& Sharpe Ratio & 35 & 0.0136 & 282 & 0.0717 & $-3.11^{* * *}$ & -2.32 \\
& Treynor Index & 35 & 0.0024 & 282 & 0.0067 & -1.61 & -2.29 \\
& & & & & \multicolumn{3}{c}{ Continued on next page } \\
\hline
\end{tabular}


Table 8 - Continued from previous page

\begin{tabular}{|c|c|c|c|c|c|c|c|}
\hline Category & measure & \multicolumn{2}{|c|}{ non-users } & \multicolumn{2}{|c|}{ heavy users } & $\begin{array}{l}\text { ttest } \\
\text { t-stat }\end{array}$ & $\begin{array}{c}\text { Wilcoxon } \\
\text { z-stat }\end{array}$ \\
\hline \multirow[t]{6}{*}{ Balanced International } & Beta & 20 & 0.4108 & 93 & 0.3127 & $1.9^{*}$ & $2.18^{* *}$ \\
\hline & Idiosyncratic Risk & 20 & 0.0017 & 93 & 0.0006 & $2.98^{* * *}$ & $2.93^{* * *}$ \\
\hline & Jensen's alpha & 20 & 0.0099 & 93 & 0.0114 & -0.83 & -0.85 \\
\hline & Appraisal Ratio & 20 & 0.1987 & 93 & 0.0624 & $4.19^{* * *}$ & $3.43^{*}$ \\
\hline & Sharpe Ratio & 20 & -0.0218 & 93 & 0.0104 & -1.28 & -1.11 \\
\hline & Treynor Index & 20 & -0.0011 & 93 & -0.0048 & 0.31 & -0.8 \\
\hline \multirow[t]{6}{*}{ Domestic Equity } & Beta & 6 & 0.8148 & 78 & 0.8871 & -0.78 & $-1.77^{*}$ \\
\hline & Idiosyncratic Risk & 6 & 0.0028 & 78 & 0.0006 & $1.83^{*}$ & $1.91^{*}$ \\
\hline & Jensen's alpha & 6 & 0.0117 & 78 & 0.0140 & -0.83 & -1.11 \\
\hline & Appraisal Ratio & 6 & 0.2668 & 78 & 0.0413 & $2.79^{* * *}$ & $2.36^{* * *}$ \\
\hline & Sharpe Ratio & 6 & 0.1492 & 78 & 0.1137 & 1.14 & $0.57^{* *}$ \\
\hline & Treynor Index & 6 & 0.0085 & 78 & 0.0076 & 0.31 & 0.28 \\
\hline \multirow[t]{6}{*}{ European Equity } & Beta & 30 & 0.8620 & 127 & 0.9506 & $-1.83^{*}$ & $-2.34^{* *}$ \\
\hline & Idiosyncratic Risk & 30 & 0.0038 & 127 & 0.0013 & $3.51^{* * *}$ & $2.53^{* *}$ \\
\hline & Jensen's alpha & 30 & 0.0251 & 127 & 0.0208 & $2.56^{* *}$ & $2.76^{* * *}$ \\
\hline & Appraisal Ratio & 30 & 0.1341 & 127 & 0.0532 & $2.62^{* * *}$ & $1.92^{* * *}$ \\
\hline & Sharpe Ratio & 30 & 0.0413 & 127 & 0.0054 & $1.71^{*}$ & $0.7^{* *}$ \\
\hline & Treynor Index & 30 & 0.0038 & 127 & 0.0024 & 0.39 & 0.71 \\
\hline \multirow[t]{6}{*}{ Fixed Income } & Beta & 34 & -0.4950 & 348 & -0.2567 & -0.57 & -1.15 \\
\hline & Idiosyncratic Risk & 34 & -0.0002 & 348 & 0.0007 & $-3.19 * * *$ & $-4.89^{* * *}$ \\
\hline & Jensen's alpha & 34 & 0.0031 & 348 & 0.0056 & $-2.36^{* *}$ & $-4.1^{* * *}$ \\
\hline & Appraisal Ratio & 34 & 0.2882 & 348 & 0.2602 & 0.32 & 0.19 \\
\hline & Sharpe Ratio & 34 & 1.7206 & 348 & 0.8769 & $5.01^{* * *}$ & $3.93^{* *}$ \\
\hline & Treynor Index & 34 & 0.0029 & 348 & 0.0052 & -0.47 & -2.06 \\
\hline \multirow[t]{6}{*}{ Foreign Equity } & Beta & 49 & 0.8944 & 211 & 0.8849 & 0.22 & 0.45 \\
\hline & Idiosyncratic Risk & 49 & 0.0014 & 211 & 0.0005 & 1.26 & 1.15 \\
\hline & Jensen's alpha & 49 & 0.0236 & 211 & 0.0278 & $-2.1^{* *}$ & $-1.74^{*}$ \\
\hline & Appraisal Ratio & 49 & 0.0456 & 211 & 0.0189 & 1.09 & 1.23 \\
\hline & Sharpe Ratio & 49 & -0.0414 & 211 & -0.0475 & 0.37 & 0.33 \\
\hline & Treynor Index & 49 & -0.0023 & 211 & -0.0029 & 0.48 & 0.58 \\
\hline \multirow[t]{6}{*}{ Money Market } & Beta & 51 & -0.0320 & 159 & 0.0089 & -0.26 & 1.37 \\
\hline & Idiosyncratic Risk & 51 & 0.0002 & 159 & 0.0002 & -0.09 & $-3.23 * * *$ \\
\hline & Jensen's alpha & 51 & 0.0011 & 159 & 0.0009 & 0.4 & -1.19 \\
\hline & Appraisal Ratio & 51 & 0.5036 & 159 & 0.5305 & -0.33 & $-1.26^{*}$ \\
\hline & Sharpe Ratio & 51 & 2.2178 & 159 & 2.1264 & 0.97 & 0.88 \\
\hline & Treynor Index & 51 & -0.0090 & 159 & 0.0034 & $-1.76^{*}$ & -0.53 \\
\hline \multirow[t]{3}{*}{ Global } & Beta & 17 & 0.3656 & 165 & 0.3359 & 0.4 & 0.14 \\
\hline & Idiosyncratic Risk & 17 & 0.0016 & 165 & 0.0002 & $1.74^{*}$ & $2.33^{* *}$ \\
\hline & Jensen's alpha & 17 & 0.0122 & 165 & 0.0172 & -1.46 & -1.56 \\
\hline
\end{tabular}


Table 8 - Continued from previous page

\begin{tabular}{llcccccc}
\hline \hline Category & measure & \multicolumn{2}{c}{ non-users } & \multicolumn{2}{c}{ heavy users } & ttest & Wilcoxon \\
& & $\mathbf{N}$ & mean & N & mean & t-stat & z-stat \\
\hline & & & & & & & \\
& & & & & & \\
& Appraisal Ratio & 17 & 0.1578 & 165 & 0.0524 & $2.64^{* * *}$ & $2.53^{* * *}$ \\
& Sharpe Ratio & 17 & 0.0509 & 165 & 0.0163 & 0.92 & $0.23^{* * *}$ \\
& Treynor Index & 17 & -0.0002 & 165 & 0.0719 & -0.43 & -0.72 \\
\hline \hline
\end{tabular}

The table presents the results for different risk and performance measures per fund category and group: heavy users and nonusers of derivatives. Funds are defined as heavy users if their frequency of derivative use is larger than the 75 percentile and their average ratio of notional value in derivatives to net asset value is larger than the 75 percentile. A t-test and a Wilcoxon test are performed on the mean and median group values, respectively. The measures are the appraisal ratio, the beta of a market model, the Jensen's alpha form a market model, the idiosyncratic risk measured by the root mean squared error of the market model, the Sharpe ratio, and the Treynor index. Computations are based on monthly returns and the management fee and the deposit fees are added back. The sample covers the period from March 1995 to March 2005 and funds with more than three years of monthly observations. Fund data is obtained from the Spanish Security and Exchange Commission, CNMV. * significant at $10 \%$; $* *$ significant at $5 \%$; $* * *$ significant at $1 \%$.

In all our exercises so far we compared the mean and the median of some performance measures, irrespectively of whether or not each one of the measures is significant at the individual fund level. This makes us wonder if we are missing superior performance of users at the individual fund level which is not reflected in the aggregates. One way of looking into this issue is to compute the fraction of funds that exhibit significant positive or negative performance. As an illustration we look at the Jensen's alpha in the market model. In Table 9, panel A, we report the fraction of funds in each category for which the parameter is significantly positive and negative in the case of returns after fees. The results are quite devastating for funds using derivatives. As we can appreciate in almost all categories users exhibit a smaller fraction of significantly positive coefficients and a larger fraction of significantly negative coefficients compared to non users of derivatives. The results in panel B put the previous result into perspective. Once fees are added back, results are not any more that devastating for derivative users. In this case the proportion of positive and significant coefficients outweighs the negative and significant coefficients, for both users and heavy users. The results reported in this table highlight again the important role of fees in the bad performance of users. Fees however fail to explain everything as in all categories (except Fixed Income and Money Market) non users still show better statistics. 
Table 9: Percentages of Significative Jensen's alpha Measures.

\begin{tabular}{|c|c|c|c|c|c|c|}
\hline \multicolumn{7}{|l|}{ Panel A } \\
\hline After Fee Returns & \multicolumn{2}{|c|}{ non-user } & \multicolumn{2}{|c|}{ user } & \multicolumn{2}{|c|}{ heavy user } \\
\hline Category & positive & negative & positive & negative & positive & negative \\
\hline Balanced Domestic & $5.7 \%$ & $57.1 \%$ & $1.4 \%$ & $57.4 \%$ & $0.0 \%$ & $68 \%$ \\
\hline Balanced International & $0.0 \%$ & $5.0 \%$ & $0.0 \%$ & $24.7 \%$ & $0.0 \%$ & $24 \%$ \\
\hline Domestic Equity & $33.3 \%$ & $0.0 \%$ & $3.8 \%$ & $39.7 \%$ & $0.0 \%$ & $33 \%$ \\
\hline European Equity & $26.7 \%$ & $10.0 \%$ & $4.7 \%$ & $18.1 \%$ & $3.6 \%$ & $7 \%$ \\
\hline Fixed Income & $2.9 \%$ & $38.2 \%$ & $3.4 \%$ & $21.6 \%$ & $2.8 \%$ & $15 \%$ \\
\hline Foreign Equity & $6.1 \%$ & $8.2 \%$ & $5.7 \%$ & $19.0 \%$ & $6.1 \%$ & $18 \%$ \\
\hline Money Market & $0.0 \%$ & $70.6 \%$ & $1.3 \%$ & $78.0 \%$ & $0.0 \%$ & $78 \%$ \\
\hline Global & $5.9 \%$ & $17.6 \%$ & $4.2 \%$ & $12.7 \%$ & $3.7 \%$ & $7 \%$ \\
\hline \multicolumn{7}{|l|}{ Panel B } \\
\hline Before-Fee Returns & \multicolumn{2}{|c|}{ non-user } & \multicolumn{2}{|c|}{ user } & heavy & user \\
\hline Category & positive & negative & positive & negative & positive & negative \\
\hline Balanced Domestic & $17.1 \%$ & $25.7 \%$ & $13.1 \%$ & $12.8 \%$ & $14.0 \%$ & $10 \%$ \\
\hline Balanced International & $35.0 \%$ & $0.0 \%$ & $14.0 \%$ & $3.2 \%$ & $11.8 \%$ & $0 \%$ \\
\hline Domestic Equity & $50.0 \%$ & $0.0 \%$ & $5.1 \%$ & $3.8 \%$ & $6.7 \%$ & $7 \%$ \\
\hline European Equity & $33.3 \%$ & $0.0 \%$ & $9.4 \%$ & $2.4 \%$ & $17.9 \%$ & $0 \%$ \\
\hline Fixed Income & $20.6 \%$ & $5.9 \%$ & $21.6 \%$ & $1.7 \%$ & $18.3 \%$ & $1 \%$ \\
\hline Foreign Equity & $10.2 \%$ & $6.1 \%$ & $10.0 \%$ & $6.2 \%$ & $10.2 \%$ & $12 \%$ \\
\hline Money Market & $43.1 \%$ & $0.0 \%$ & $51.6 \%$ & $0.0 \%$ & $50.0 \%$ & $0 \%$ \\
\hline Global & $29.4 \%$ & $0.0 \%$ & $17.6 \%$ & $4.8 \%$ & $7.4 \%$ & $7 \%$ \\
\hline
\end{tabular}

The table presents the percentages of positive or negative and significant Jensen's alpha coefficients within each category and group. Groups of funds are non-users, users, and heavy users of derivatives. Heavy users are selected if their frequency of derivative use is larger than the 75 percentile and their average ratio of notional value in derivatives to net asset value is larger than the 75 percentile. A coefficient is considered to be significant if it is significant at the $10 \%$ confidence level. Panel A reports after fee results, while panel $\mathrm{B}$ reports before fee results. The sample covers the period from March 1995 to March 2005. Fund data is obtained from the Spanish Security and Exchange Commission, CNMV. * significant at $10 \%$; ** significant at $5 \%$; *** significant at $1 \%$.

\subsection{Selectivity and Timing Skills}

As stated in the introduction, funds may use derivatives to time the market. The previous analysis do not explicitly test for timing skills. To complete our performance evaluation analysis we explicitly test for the existence of superior timing skill among users of derivatives in the context of the Treynor-Mazuy (1966) model, which is the most widely used model for this purpose. This model extends the market model by incorporating a factor that captures market increases. This factor is defined as the square of the market excess return. The model takes the form:

$$
r_{i, t}-r_{f, t}=\alpha_{i}+\beta_{i} *\left(r_{m, t}-r_{f, t}\right)+\beta_{\text {timing }, i} *\left(r_{m, t}-r_{f, t}\right)^{2}+\varepsilon_{i, t}
$$

where $r_{i, t}$ is the fund's return, $r_{f, t}$ is the risk free rate, and $r_{m, t}$ is the market's return.

This model allows for the separation of timing and selectivity skills in fund man- 
agement. The ability to select stocks is associated to a positive alpha while timing skills correspond to a positive market timing coefficient $\beta_{\text {timing, } i}$. The previous literature typically reports negative values for the $\beta_{\text {timing }}$ coefficient (Ferson and Shadt (1996) Cumby and Glenn (1990), among others) and denotes the result as a "perverse" outcome. Regarding the alpha coefficient, it is well recognized by now that if there is market timing in a fund, then the alpha is biased downwards.

In Tables 10 to 13 we report the results of the estimation of the model. Table 10 and Table 11 correspond to the case of after fees returns for users and heavy users, respectively; Table 12 and Table 13 correspond to the case of before fees returns for users and heavy users, respectively.

Regarding timing skills, in almost all the cases we find no significant differences between users and non users of derivatives. The exceptions are the Balance Domestic and the European Equity categories where the timing coefficient is significantly superior in all cases (before and after fees and for users and heavy users). Notice that the coefficient for the market timing of European Equity funds is even positive. Regarding the alpha or selectivity parameter, we only find superior selectivity skills in the Fixed Income category (in all cases). In the rest of categories the selectivity skills of users is worst or not significantly different to the one of non users.

To conclude, our performance evaluation study results in a very negative picture of derivatives usage in the Spanish Mutual fund industry. We only find a fund category, Fixed income, that exhibits some (weak) signs of superior performance. We identify high fees as one variable that partially explain the poor performance of users. We do not find evidence on heavy users being better derivative traders that users.

\section{Derivatives Usage and Return Distributions}

The mean variance setting is restrictive as it summarizes risk in a single parameter, the volatility of the return. Investors may have a clear preference for other moments 
Table 10: Selectivity and Timing Skills Of Users.

\begin{tabular}{|c|c|c|c|c|c|c|c|}
\hline \multirow[b]{2}{*}{ Category } & \multirow[b]{2}{*}{ Measure } & \multicolumn{2}{|c|}{ non-users } & \multicolumn{2}{|c|}{ users } & \multirow[b]{2}{*}{ ttest t-stat } & \multirow[b]{2}{*}{ Wilcoxon z-stat } \\
\hline & & $\mathbf{N}$ & mean & $\mathbf{N}$ & mean & & \\
\hline \multirow{2}{*}{ Balanced Domestic } & mkt timing & 35 & -0.5072 & 282 & -0.1692 & $-4.44^{* * *}$ & $-3.39 * * *$ \\
\hline & selectivity & 35 & -0.0004 & 282 & -0.0012 & $2.77 * * *$ & $2.63^{* * *}$ \\
\hline \multirow[t]{2}{*}{ Balanced International } & mkt timing & 20 & -0.2009 & 93 & -0.1293 & -0.47 & -0.59 \\
\hline & selectivity & 20 & 0.0008 & 93 & -0.0003 & $2.63^{* * *}$ & $2.74^{* * *}$ \\
\hline \multirow[t]{2}{*}{ Domestic Equity } & mkt timing & 6 & -0.1698 & 78 & -0.2877 & 0.54 & 0.26 \\
\hline & selectivity & 6 & 0.0019 & 78 & -0.0001 & 1.38 & $2.33^{* *}$ \\
\hline \multirow{2}{*}{ European Equity } & mkt timing & 30 & -0.4447 & 127 & 0.0070 & $-2^{* *}$ & $-1.94 *$ \\
\hline & selectivity & 30 & 0.0034 & 127 & -0.0003 & $4.42^{* * *}$ & $3.15^{* * *}$ \\
\hline \multirow[t]{2}{*}{ Fixed Income } & mkt timing & 34 & -241.4907 & 348 & -146.1361 & -0.36 & -1.19 \\
\hline & selectivity & 34 & -0.0012 & 348 & -0.0006 & -1.11 & $-2.3^{* *}$ \\
\hline \multirow[t]{2}{*}{ Foreign Equity } & mkt timing & 49 & -0.5803 & 211 & -0.4209 & -0.75 & -0.65 \\
\hline & selectivity & 49 & 0.0016 & 211 & 0.0003 & 1.42 & 1.32 \\
\hline \multirow[t]{2}{*}{ Money Market } & mkt timing & 51 & -4.1428 & 159 & -1.0561 & -0.03 & -0.47 \\
\hline & selectivity & 51 & -0.0005 & 159 & -0.0002 & -0.62 & -0.41 \\
\hline \multirow[t]{2}{*}{ Global } & mkt timing & 17 & -0.4269 & 165 & -0.3525 & -0.27 & -0.62 \\
\hline & selectivity & 17 & 0.0014 & 165 & 0.0000 & $1.74^{*}$ & $1.66^{*}$ \\
\hline
\end{tabular}

The table presents the results for the selectivity and the market timing coefficients, per fund category and group, in the context of the Treynor-Mazuy (1966) model. Groups are users and nonusers of derivatives. A t-test and a Wilcoxon test are performed on the mean group values respectively. Returns are computed on a monthly basis. The sample covers the period March 1995 to March 2005 and funds with more than three years of monthly observations. Fund data is obtained from the Spanish Security and Exchange Commission, CNMV. * significant at 10\%; ** significant at $5 \%$; *** significant at $1 \%$.

of the distribution. For instance, other things equal, investors may have a preference for small shortfall risk. For this reason it is interesting to look at other moments of the distribution to see if funds offer return characteristics of interests for investors. Analyzing the return distributions is also of interest as it may shed light on the reasons behind derivatives usage. As discussed in the introduction, we should expect some differences in return distributions when derivatives are used for speculation versus risk management/hedging.

In this section we analyze the impact of derivative use on the distribution of returns. We compute the four central moments and the $10 \%$ tails of the distribution of the monthly returns for each fund for the whole time period and compare the 
Table 11: Selectivity and Timing Skills of Heavy Users.

\begin{tabular}{|c|c|c|c|c|c|c|c|}
\hline \multirow[b]{2}{*}{ Category } & \multirow[b]{2}{*}{ Measure } & \multicolumn{2}{|c|}{ non-users } & \multicolumn{2}{|c|}{ heavy users } & \multirow[b]{2}{*}{ ttest t-stat } & \multirow[b]{2}{*}{ Wilcoxon z-stat } \\
\hline & & $\mathbf{N}$ & mean & $\mathbf{N}$ & mean & & \\
\hline \multirow[t]{2}{*}{ Balanced Domestic } & mkt timing & 35 & -0.5072 & 50 & -0.2358 & $-2.35^{* *}$ & $-2.11^{* *}$ \\
\hline & selectivity & 35 & -0.0004 & 50 & -0.0011 & 1.59 & $2.02^{* *}$ \\
\hline \multirow[t]{2}{*}{ Balanced International } & mkt timing & 20 & -0.2009 & 17 & -0.2559 & 0.25 & 0.24 \\
\hline & selectivity & 20 & 0.0008 & 17 & -0.0003 & $1.86^{*}$ & $1.8^{*}$ \\
\hline \multirow[t]{2}{*}{ Domestic Equity } & mkt timing & 6 & -0.1698 & 15 & -0.1286 & -0.34 & -0.16 \\
\hline & selectivity & 6 & 0.0019 & 15 & -0.0008 & $2.82^{* *}$ & $2.41^{* *}$ \\
\hline \multirow{2}{*}{ European Equity } & mkt timing & 30 & -0.4447 & 28 & 0.1277 & $-2.17^{* *}$ & $-1.85^{*}$ \\
\hline & selectivity & 30 & 0.0034 & 28 & 0.0007 & $2.18^{* *}$ & 1.52 \\
\hline \multirow[t]{2}{*}{ Fixed Income } & mkt timing & 34 & -241.4907 & 71 & -133.9700 & -0.39 & -0.1 \\
\hline & selectivity & 34 & -0.0012 & 71 & -0.0003 & -1.5 & $-2.35^{* *}$ \\
\hline \multirow[t]{2}{*}{ Foreign Equity } & mkt timing & 49 & -0.5803 & 49 & -0.3716 & -0.86 & -0.44 \\
\hline & selectivity & 49 & 0.0016 & 49 & 0.0003 & 1.08 & 0.52 \\
\hline \multirow[t]{2}{*}{ Money Market } & mkt timing & 51 & -4.1428 & 40 & 58.2579 & -1.29 & -0.1 \\
\hline & selectivity & 51 & -0.0005 & 40 & 0.0000 & -0.98 & -0.2 \\
\hline \multirow[t]{2}{*}{ Global } & mkt timing & 17 & -0.4269 & 27 & -0.5620 & 0.34 & -0.28 \\
\hline & selectivity & 17 & 0.0014 & 27 & -0.0005 & $1.79^{*}$ & 1.1 \\
\hline
\end{tabular}

The table presents the results for the selectivity and the market timing coefficients, per fund category and group, in the context of the Treynor-Mazuy (1966) model. Groups are heavy users and non users of derivatives. Funds are defined as heavy users if their frequency of derivative use is larger than the 75 percentile and their average ratio of notional value in derivatives to net asset value is larger than the 75 percentile. A t-test and a Wilcoxon test are performed on the mean group values respectively. Returns are computed on a monthly basis. The sample covers the period March 1995 to March 2005 and funds with more than three years of monthly observations. Fund data is obtained from the Spanish Security and Exchange Commission, CNMV. * significant at $10 \%$; ** significant at $5 \%$; *** significant at $1 \%$.

results for users versus non users of derivatives. ${ }^{18}$ Before reporting the results it is convenient to briefly discuss the results we should expect under particular hypothesis.

The ideal scenario of efficient use of derivatives would be one in which the return of users exhibit larger mean, lower volatility, larger skewness and a larger breakpoint for both the lower and upper $10 \%$ tail of the distribution. In our discussion below we will refer to superperformers to users in some category that exhibit robust evidence in at least four of the previous five conditions. On the other hand, if derivatives were successfully used for speculation we should expect the distribution of returns to exhibit either larger mean or larger skewness, and a larger breakpoint for the upper $10 \%$ tail. When one of the first two conditions are met and the latter condition too

\footnotetext{
${ }^{18} \mathrm{It}$ is important to remember that in order to have better estimates of the distribution of returns in the filtering of our data set we excluded all funds with less than three years of observations.
} 
Table 12: Selectivity and Timing Skills Before Fees Of Users.

\begin{tabular}{|c|c|c|c|c|c|c|c|}
\hline \multirow[b]{2}{*}{ Category } & \multirow[b]{2}{*}{ Measure } & \multicolumn{2}{|c|}{ non-users } & \multicolumn{2}{|c|}{ users } & \multirow[b]{2}{*}{ ttest t-stat } & \multirow[b]{2}{*}{ Wilcoxon z-stat } \\
\hline & & $\mathbf{N}$ & mean & $\mathbf{N}$ & mean & & \\
\hline \multirow[t]{2}{*}{ Balanced Domestic } & mkt timing & 35 & -0.4935 & 282 & -0.1701 & $-4.26^{* * *}$ & $-3.29 * * *$ \\
\hline & selectivity & 35 & 0.0007 & 282 & 0.0002 & $1.84^{*}$ & 1.41 \\
\hline \multirow[t]{2}{*}{ Balanced International } & mkt timing & 20 & -0.2043 & 93 & -0.1286 & -0.49 & -0.67 \\
\hline & selectivity & 20 & 0.0022 & 93 & 0.0010 & $2.85^{* * *}$ & $2.93^{* * *}$ \\
\hline \multirow[t]{2}{*}{ Domestic Equity } & mkt timing & 6 & -0.1686 & 78 & -0.2882 & 0.55 & 0.28 \\
\hline & selectivity & 6 & 0.0033 & 78 & 0.0015 & 1.26 & $2.08^{* *}$ \\
\hline \multirow[t]{2}{*}{ European Equity } & mkt timing & 30 & -0.4441 & 127 & 0.0047 & $-1.99 * *$ & $-1.93^{*}$ \\
\hline & selectivity & 30 & 0.0049 & 127 & 0.0013 & $4.26^{* * *}$ & $3.05^{* * *}$ \\
\hline \multirow[t]{2}{*}{ Fixed Income } & mkt timing & 34 & -262.1762 & 348 & -144.4942 & -0.44 & -1.34 \\
\hline & selectivity & 34 & -0.0005 & 348 & 0.0005 & $-1.85^{*}$ & $-3.15^{* * *}$ \\
\hline \multirow[t]{2}{*}{ Foreign Equity } & mkt timing & 49 & -0.5806 & 211 & -0.4229 & -0.74 & -0.65 \\
\hline & selectivity & 49 & 0.0032 & 211 & 0.0018 & 1.43 & 1.35 \\
\hline \multirow[t]{2}{*}{ Money Market } & mkt timing & 51 & 3.5188 & 159 & 1.8403 & 0.02 & -0.38 \\
\hline & selectivity & 51 & 0.0004 & 159 & 0.0007 & -0.65 & -1.12 \\
\hline \multirow[t]{2}{*}{ Global } & mkt timing & 17 & -0.4326 & 165 & -0.3559 & -0.27 & -0.61 \\
\hline & selectivity & 17 & 0.0027 & 165 & 0.0011 & $1.84^{*}$ & 1.62 \\
\hline
\end{tabular}

The table presents the results for the selectivity and the market timing coefficients, per fund category and group, in the context of the Treynor-Mazuy (1966) model. Groups are users and nonusers of derivatives. A t-test and a Wilcoxon test are performed on the mean group values respectively. Computations are based on monthly returns and the management fee and the deposit fees are added back. The sample covers the period March 1995 to March 2005 and funds with more than three years of monthly observations. Fund data is obtained from the Spanish Security and Exchange Commission, CNMV. ${ }^{*}$ significant at $10 \%$; ${ }^{* *}$ significant at $5 \%$; $* * *$ significant at $1 \%$.

we will refer to this situation as a case of successful speculation. When the opposite conditions are met, that is if the distributions of returns exhibit a larger standard deviation, or a smaller breakpoint for the lower 10\% tail and a larger breakpoint for the upper $10 \%$ tail, and no positive effect on mean or skewness is reported we will refer to this situation as a case of unsuccessful speculation. Finally, if derivatives were used for risk management/hedging purposes we should expect a lower volatility, lower kurtosis and a larger breakpoint for the lower $10 \%$ tail. When these three conditions are met in some fund category we will refer to this situation as a case of hedging.

As in the analysis in the previous section, funds are grouped in their respective categories. Within each category we separate funds that use derivatives using both the definition of users and heavy users. The analysis cover both the case of returns before and after fees. The mean of each measure is computed for each group and 
Table 13: Selectivity and Timing Skills Before Fees Of Heavy Users.

\begin{tabular}{|c|c|c|c|c|c|c|c|}
\hline \multirow[b]{2}{*}{ Category } & \multirow[b]{2}{*}{ Measure } & \multicolumn{2}{|c|}{ "non-users } & \multicolumn{2}{|c|}{ heavy users } & \multirow[b]{2}{*}{ ttest t-stat } & \multirow[b]{2}{*}{ Wilcoxon z-stat } \\
\hline & & $\mathbf{N}$ & mean & $\mathbf{N}$ & mean & & \\
\hline \multirow[t]{2}{*}{ Balanced Domestic } & mkt timing & 35 & -0.4935 & 50 & -0.2369 & $-2.25^{* *}$ & $-2.01^{* *}$ \\
\hline & selectivity & 35 & 0.0007 & 50 & 0.0004 & 0.84 & 0.86 \\
\hline \multirow[t]{2}{*}{ Balanced International } & mkt timing & 20 & -0.2043 & 17 & -0.2589 & 0.25 & 0.24 \\
\hline & selectivity & 20 & 0.0022 & 17 & 0.0009 & $2.31^{* *}$ & $2.1^{* *}$ \\
\hline \multirow[t]{2}{*}{ Domestic Equity } & mkt timing & 6 & -0.1686 & 15 & -0.1277 & -0.34 & -0.16 \\
\hline & selectivity & 6 & 0.0033 & 15 & 0.0006 & $2.78^{* *}$ & $2.49^{* *}$ \\
\hline \multirow{2}{*}{ European Equity } & mkt timing & 30 & -0.4441 & 28 & 0.1265 & $-2.16^{* *}$ & $-1.81 *$ \\
\hline & selectivity & 30 & 0.0049 & 28 & 0.0021 & $2.2^{* *}$ & 1.57 \\
\hline \multirow[t]{2}{*}{ Fixed Income } & mkt timing & 34 & -262.1762 & 71 & -149.3526 & -0.41 & -0.16 \\
\hline & selectivity & 34 & -0.0005 & 71 & 0.0008 & $-2.1^{* *}$ & $-3.02 * * *$ \\
\hline \multirow[t]{2}{*}{ Foreign Equity } & mkt timing & 49 & -0.5806 & 49 & -0.3765 & -0.84 & -0.39 \\
\hline & selectivity & 49 & 0.0032 & 49 & 0.0018 & 1.18 & 0.65 \\
\hline \multirow[t]{2}{*}{ Money Market } & mkt timing & 51 & 3.5188 & 40 & 63.2440 & -1.27 & -0.62 \\
\hline & selectivity & 51 & 0.0004 & 40 & 0.0009 & -1.28 & -1.61 \\
\hline \multirow[t]{2}{*}{ Global } & mkt timing & 17 & -0.4326 & 27 & -0.5665 & 0.34 & -0.25 \\
\hline & selectivity & 17 & 0.0027 & 27 & 0.0006 & $1.8^{*}$ & 1.29 \\
\hline
\end{tabular}

The table presents the results for the selectivity and the market timing coefficients, per fund category and group, in the context of the Treynor-Mazuy (1966) model. Groups are heavy users and nonusers of derivatives. Funds are defined as heavy users if their frequency of derivative use is larger than the 75 percentile and their average ratio of notional value in derivatives to net asset value is larger than the 75 percentile. A t-test and a Wilcoxon test are performed on the mean group values respectively. Computations are based than the 75 percentile. A t-test and a Wilcoxon test are performed on the mean group values respectively. Computations are based
on monthly returns and the management fee and the deposit fees are added back. The sample covers the period March 1995 to March 2005 and funds with more than three years of monthly observations. Fund data is obtained from the Spanish Security and Exchange Commission, CNMV. * significant at $10 \% ; * *$ significant at $5 \% ; * * *$ significant at $1 \%$.

fund category. Finally, we compare the mean values for each group and measure and compute the t-statistic for the difference in group means and the Wilcoxon test on the group medians. The results are reported in tables 14, 15, 16, and 17.

The first observation is that we find three categories (Global, Money Market and Foreign Equity) in which returns are not significantly different for users versus non users. This result is robust to almost all specifications: returns before and after fees, and users as well as heavy users. The second observation is that we do not find a single category in which users of derivatives can be classified as superperformers. If we relax the definition of superperfromance, asking for just three rather than four of the five conditions in the definition, we find some positive evidence in two categories. In particular, we find that user, but not heavy users, in the Balance Domestic and 
Balance International categories can be classified as superprformers. The third result is that we do not find a single category in which users can be cataloged as hedgers. That is, from the analysis of the distribution of returns no fund category reports evidence of using derivatives for hedging or risk management purposes, according to our definition. Regarding the use of derivatives for speculation purposes, we find two categories (Domestic Equity and European Equity ) in which users can be classified as unsuccessful speculators, and just one category (Fixed Income) in which users can be classified as successful speculators.

Table 14: Return Distributions of Users.

\begin{tabular}{|c|c|c|c|c|c|c|c|}
\hline \multirow[t]{2}{*}{ Category } & \multirow[t]{2}{*}{ measure } & \multicolumn{2}{|c|}{ non-users } & \multicolumn{2}{|c|}{ users } & \multirow{2}{*}{$\begin{array}{c}\text { ttest } \\
\text { t-stat }\end{array}$} & \multirow{2}{*}{$\begin{array}{c}\text { Wilcoxon } \\
\text { z-stat }\end{array}$} \\
\hline & & $\mathbf{N}$ & mean & $\mathbf{N}$ & mean & & \\
\hline \multirow{7}{*}{ Balanced Domestic } & & $11 \%$ & & $89 \%$ & & & \\
\hline & mean & 35 & 0.0020 & 282 & 0.0030 & $-2.16^{* *}$ & $-2.32^{* *}$ \\
\hline & sd & 35 & 0.0238 & 282 & 0.0217 & 0.94 & 1.05 \\
\hline & skewness & 35 & -0.4585 & 282 & -0.2328 & $-2.5^{* *}$ & $-2.5^{* *}$ \\
\hline & kurtosis & 35 & 4.1995 & 282 & 4.3622 & -0.45 & -0.16 \\
\hline & 10th centile & 35 & -0.0282 & 282 & -0.0233 & $-1.75^{*}$ & $-1.83^{*}$ \\
\hline & 90th centile & 35 & 0.0304 & 282 & 0.0281 & 0.81 & 0.69 \\
\hline \multirow{7}{*}{ Balanced International } & & $18 \%$ & & $82 \%$ & & & \\
\hline & mean & 20 & 0.0005 & 93 & 0.0015 & $-1.73^{*}$ & $-2.05^{* *}$ \\
\hline & $\mathrm{sd}$ & 20 & 0.0230 & 93 & 0.0202 & 0.97 & 1.41 \\
\hline & skewness & 20 & -0.6463 & 93 & -0.2760 & $-2.08^{* *}$ & $-2.63^{* * *}$ \\
\hline & kurtosis & 20 & 3.5229 & 93 & 4.5076 & -1.49 & $-2.22^{* *}$ \\
\hline & 10th centile & 20 & -0.0305 & 93 & -0.0234 & $-1.76^{*}$ & $-2.17^{* *}$ \\
\hline & 90th centile & 20 & 0.0267 & 93 & 0.0239 & 0.82 & 1.43 \\
\hline \multirow{7}{*}{ Domestic Equity } & & $7 \%$ & & $93 \%$ & & & \\
\hline & mean & 6 & 0.0078 & 78 & 0.0073 & 0.37 & 0.28 \\
\hline & sd & 6 & 0.0467 & 78 & 0.0546 & -1.61 & $-2.52^{* *}$ \\
\hline & skewness & 6 & -0.3791 & 78 & -0.2664 & -0.93 & -0.76 \\
\hline & kurtosis & 6 & 3.6254 & 78 & 3.5964 & 0.11 & 0.14 \\
\hline & 10th centile & 6 & -0.0529 & 78 & -0.0593 & 0.94 & 1.49 \\
\hline & 90th centile & 6 & 0.0651 & 78 & 0.0779 & -1.65 & $-2.15^{* *}$ \\
\hline \multirow{7}{*}{ European Equity } & & $19 \%$ & & $81 \%$ & & & \\
\hline & mean & 30 & 0.0027 & 127 & 0.0011 & 1.55 & 0.77 \\
\hline & & 30 & 0.0520 & 127 & 0.0536 & -0.69 & -0.95 \\
\hline & skewness & 30 & -0.5563 & 127 & -0.5257 & -0.41 & -0.48 \\
\hline & kurtosis & 30 & 3.8500 & 127 & 3.8238 & 0.12 & 1.15 \\
\hline & 10th centile & 30 & -0.0668 & 127 & -0.0701 & 0.75 & 0.52 \\
\hline & 90th centile & 30 & 0.0611 & 127 & 0.0631 & -0.67 & -1.07 \\
\hline \multirow{3}{*}{ Fixed Income } & & $9 \%$ & & $91 \%$ & & & \\
\hline & mean & 34 & 0.0022 & 348 & 0.0031 & $-3.44^{* * *}$ & $-5.02 * * *$ \\
\hline & sd & 34 & 0.0035 & 348 & 0.0061 & $-2.51^{* *}$ & -4.39 *** \\
\hline
\end{tabular}


Table 14 - Continued from previous page

\begin{tabular}{llcccccc}
\hline \hline Category & measure & \multicolumn{2}{c}{ non-users } & \multicolumn{2}{c}{ users } & ttest & Wilcoxon \\
& & $\mathbf{N}$ & mean & $\mathbf{N}$ & mean & t-stat & z-stat \\
\hline & skewness & 34 & 0.1273 & 348 & 0.2398 & -0.63 & 0.83 \\
& kurtosis & 34 & 4.8619 & 348 & 4.9742 & -0.12 & $-3.35^{* * *}$ \\
& 10th centile & 34 & -0.0018 & 348 & -0.0041 & $1.69^{*}$ & $3.6^{* * *}$ \\
& 90th centile & 34 & 0.0060 & 348 & 0.0100 & $-3.65^{* * *}$ & $-4.67^{* * *}$ \\
& & & & & & & \\
Foreign Equity & $\mathbf{1 9 \%}$ & & $\mathbf{8 1 \%}$ & & & \\
& mean & 49 & -0.0013 & 211 & -0.0022 & 0.83 & 0.41 \\
& sd & 49 & 0.0559 & 211 & 0.0572 & -0.51 & -0.09 \\
& skewness & 49 & -0.4410 & 211 & -0.3842 & -0.87 & -0.61 \\
& kurtosis & 49 & 3.4423 & 211 & 3.5880 & -0.97 & 0.18 \\
& 10th centile & 49 & -0.0745 & 211 & -0.0780 & 0.8 & 0.71 \\
& 90th centile & 49 & 0.0634 & 211 & 0.0643 & -0.29 & -0.11 \\
& & & & & & & \\
& mean & $\mathbf{2 4 \%}$ & & $\mathbf{7 6 \%}$ & & & \\
& sd & 51 & 0.0029 & 159 & 0.0028 & 0.76 & 0.58 \\
& skewness & 51 & 0.9277 & 159 & 0.0019 & 0.3 & -0.26 \\
& kurtosis & 51 & 4.5274 & 159 & 0.7348 & 1.04 & -0.16 \\
& 10th centile & 51 & 0.0011 & 159 & 0.0008 & -0.24 & -0.48 \\
90th centile & 51 & 0.0053 & 159 & 0.0057 & -0.86 & -0.88 \\
& & & & & & & \\
& & $\mathbf{9 \%}$ & & $\mathbf{9 1 \%}$ & & & \\
& mean & 17 & 0.0010 & 165 & 0.0012 & -0.16 & -0.81 \\
& sd & 17 & 0.0232 & 165 & 0.0253 & -0.46 & -0.44 \\
& skewness & 17 & -0.6062 & 165 & -0.2614 & -1.49 & -1.48 \\
& kurtosis & 17 & 6.8704 & 165 & 5.5960 & 1.32 & -0.1 \\
10th centile & 17 & -0.0304 & 165 & -0.0297 & -0.12 & 0.41 \\
& 90th centile & 17 & 0.0266 & 165 & 0.0286 & -0.41 & -0.56 \\
\hline \hline
\end{tabular}

This table presents the four main central moments, the 10th and 90th percentiles of the funds' distribution of returns per category and group. Groups are nonusers and users of derivatives. A t-test and a Wilcoxon test are performed on the mean and median group values moments' measures are the returns' mean, the returns' standard deviation the returns' skewness, and the returns' kurtosis . Returns are computed on a monthly basis. The sample covers the period from March 1995 to March 2005 and funds with more than three years of monthly observations. Fund data is obtained from the Spanish Security and Exchange Commission, CNMV. * significant at $10 \%$; ** significant at $5 \% ; * * *$ significant at $1 \%$.

Table 15: Return Distributions of Heavy Users.

\begin{tabular}{llcccccc}
\hline Category & measure & \multicolumn{2}{c}{ non-users } & \multicolumn{2}{c}{ heavy users } & ttest & Wilcoxon \\
& & N & mean & N & mean & t-stat & z-stat \\
\hline Balanced Domestic & mean & 35 & 0.0020 & 50 & 0.0028 & -1.15 & -1.51 \\
& sd & 35 & 0.0238 & 50 & 0.0225 & 0.49 & 0.63 \\
& skewness & 35 & -0.4585 & 50 & -0.2529 & $-2.06^{* *}$ & $-2.14^{* *}$ \\
& kurtosis & 35 & 4.1995 & 50 & 3.9530 & 0.75 & 1.47 \\
& 10th centile & 35 & -0.0282 & 50 & -0.0244 & -1.09 & -1.22 \\
& 90th centile & 35 & 0.0304 & 50 & 0.0296 & 0.2 & 0.09 \\
Balanced International & mean & 20 & 0.0005 & 17 & 0.0009 & -0.63 & -0.64 \\
& sd & 20 & 0.0230 & 17 & 0.0205 & 0.64 & 1.49 \\
& skewness & 20 & -0.6463 & 17 & -0.5661 & -0.64 & -0.15 \\
& kurtosis & 20 & 3.5229 & 17 & 4.1375 & $-2.22^{* *}$ & $-1.83^{*}$ \\
& 10th centile & 20 & -0.0305 & 17 & -0.0249 & -1 & $-1.68^{*}$ \\
& 90th centile & 20 & 0.0267 & 17 & 0.0246 & 0.47 & 1.25
\end{tabular}


Table 15 - Continued from previous page

\begin{tabular}{|c|c|c|c|c|c|c|c|}
\hline \multirow[t]{2}{*}{ Category } & \multirow[t]{2}{*}{ measure } & \multicolumn{2}{|c|}{ non-users } & \multicolumn{2}{|c|}{ heavy users } & \multirow{2}{*}{$\begin{array}{l}\text { ttest } \\
\text { t-stat }\end{array}$} & \multirow{2}{*}{$\begin{array}{c}\text { Wilcoxon } \\
\text { z-stat }\end{array}$} \\
\hline & & $\mathbf{N}$ & mean & $\mathbf{N}$ & mean & & \\
\hline \multirow{6}{*}{ Domestic Equity } & mean & 6 & 0.0078 & 15 & 0.0065 & 0.75 & 0.7 \\
\hline & sd & 6 & 0.0467 & 15 & 0.0613 & $-5.13^{* * *}$ & $-3.43^{* * *}$ \\
\hline & skewness & 6 & -0.3791 & 15 & -0.2726 & -1.09 & -0.7 \\
\hline & kurtosis & 6 & 3.6254 & 15 & 3.4088 & 1.42 & 0.7 \\
\hline & 10th centile & 6 & -0.0529 & 15 & -0.0688 & $2.81^{* *}$ & $2.26^{* *}$ \\
\hline & 90th centile & 6 & 0.0651 & 15 & 0.0882 & $-4.05^{* * *}$ & $-3.04^{* * *}$ \\
\hline \multirow[t]{6}{*}{ European Equity } & mean & 30 & 0.0027 & 28 & 0.0006 & 1.34 & 0.98 \\
\hline & sd & 30 & 0.0520 & 28 & 0.0563 & -1.65 & $-2.18^{* *}$ \\
\hline & skewness & 30 & -0.5563 & 28 & -0.6527 & 0.99 & 0.78 \\
\hline & kurtosis & 30 & 3.8500 & 28 & 3.8697 & -0.07 & 0.75 \\
\hline & 10th centile & 30 & -0.0668 & 28 & -0.0760 & $1.72^{*}$ & $1.71^{*}$ \\
\hline & 90th centile & 30 & 0.0611 & 28 & 0.0665 & -1.35 & $-1.74^{*}$ \\
\hline \multirow[t]{6}{*}{ Fixed Income } & mean & 34 & 0.0022 & 71 & 0.0032 & $-2.77^{* * *}$ & $-4.66^{* * *}$ \\
\hline & sd & 34 & 0.0035 & 71 & 0.0080 & $-3.58^{* * *}$ & $-5.13 * * *$ \\
\hline & skewness & 34 & 0.1273 & 71 & 0.1782 & -0.24 & 1.61 \\
\hline & kurtosis & 34 & 4.8619 & 71 & 4.5212 & 0.3 & $-2.39 * *$ \\
\hline & 10th centile & 34 & -0.0018 & 71 & -0.0064 & $2.76^{* * *}$ & $4.97^{* * *}$ \\
\hline & 90th centile & 34 & 0.0060 & 71 & 0.0122 & $-4.9 * * *$ & $-5.31^{* * *}$ \\
\hline \multirow[t]{6}{*}{ Foreign Equity } & mean & 49 & -0.0013 & 49 & -0.0038 & $2.04^{* *}$ & $2.11^{* *}$ \\
\hline & $\mathrm{sd}$ & 49 & 0.0559 & 49 & 0.0586 & -0.86 & -0.07 \\
\hline & skewness & 49 & -0.4410 & 49 & -0.3363 & -1.48 & -1.28 \\
\hline & kurtosis & 49 & 3.4423 & 49 & 3.1245 & $2.75^{* * *}$ & $2.82^{* * *}$ \\
\hline & 10th centile & 49 & -0.0745 & 49 & -0.0826 & $1.68^{*}$ & $1.65^{*}$ \\
\hline & 90th centile & 49 & 0.0634 & 49 & 0.0663 & -0.74 & -0.47 \\
\hline \multirow[t]{6}{*}{ Money Market } & mean & 51 & 0.0029 & 40 & 0.0029 & -0.06 & -0.61 \\
\hline & sd & 51 & 0.0021 & 40 & 0.0018 & 0.74 & -1.08 \\
\hline & skewness & 51 & 0.9277 & 40 & 0.9271 & 0 & -0.62 \\
\hline & kurtosis & 51 & 4.5274 & 40 & 4.1767 & 0.29 & -0.04 \\
\hline & 10th centile & 51 & 0.0011 & 40 & 0.0010 & 0.79 & 0.2 \\
\hline & 90th centile & 51 & 0.0053 & 40 & 0.0056 & -1.05 & -1.58 \\
\hline \multirow[t]{6}{*}{ Global } & mean & 17 & 0.0010 & 27 & 0.0002 & 0.46 & -0.23 \\
\hline & sd & 17 & 0.0232 & 27 & 0.0276 & -0.64 & -0.47 \\
\hline & skewness & 17 & -0.6062 & 27 & -0.5532 & -0.16 & -0.47 \\
\hline & kurtosis & 17 & 6.8704 & 27 & 5.3956 & 0.93 & 0.59 \\
\hline & 10th centile & 17 & -0.0304 & 27 & -0.0306 & 0.01 & 0.49 \\
\hline & 90th centile & 17 & 0.0266 & 27 & 0.0282 & -0.27 & -0.42 \\
\hline
\end{tabular}

This table presents the four main central moments, the 10th and 90th percentiles of the funds' distribution of returns per category and group. Groups are non users and heavy users of derivatives. Funds are defined as heavy users if their frequency of derivative use is larger than the 75 percentile and their average ratio of notional value in derivatives to net asset value is larger than the 75 percentile. A t-test and a Wilcoxon test are performed on the mean and median group values per category respectively. The central moments' measures are the returns' mean, the returns' standard deviation, the returns' skewness, and the returns' kurtosis. Returns are computed on a monthly basis and the management fee and the deposit fees are added back.. The sample covers the period from March 1995 to March 2005 and funds with more than three years of monthly observations. Fund data is obtained from the Spanish Security and Exchange Commission, CNMV. $*$ significant at $10 \%$; ** significant at $5 \%$; *** significant at $1 \%$.

Table 16: Before Fees Return Distributions of Users.

\begin{tabular}{lllccccc|}
\hline \hline Category & measure & \multicolumn{2}{c}{ non-users } & \multicolumn{2}{c}{ users } & ttest & Wilcoxon \\
& & $\mathbf{N}$ & mean & $\mathbf{N}$ & mean & t-stat & z-stat \\
\hline Balanced Domestic & mean & 35 & 0.0031 & 282 & 0.0044 & $-2.63^{* * *}$ & $-2.76^{* * *}$ \\
\hline & & & & & & \multicolumn{2}{c}{ Continued on next page } \\
\hline
\end{tabular}


Table 16 - Continued from previous page

\begin{tabular}{|c|c|c|c|c|c|c|c|}
\hline \multirow[t]{2}{*}{ Category } & \multirow[t]{2}{*}{ measure } & \multicolumn{2}{|c|}{ "non-users } & \multicolumn{2}{|c|}{ users } & \multirow{2}{*}{$\begin{array}{c}\text { ttest } \\
\text { t-stat }\end{array}$} & \multirow{2}{*}{$\begin{array}{c}\text { Wilcoxon } \\
\text { z-stat }\end{array}$} \\
\hline & & $\mathbf{N}$ & mean & $\mathbf{N}$ & mean & & \\
\hline & sd & 35 & 0.0238 & 282 & 0.0217 & 0.92 & 1.03 \\
\hline & skewness & 35 & -0.4485 & 282 & -0.2314 & $-2.38 * *$ & $-2.41 * *$ \\
\hline & kurtosis & 35 & 4.2059 & 282 & 4.3650 & -0.43 & -0.12 \\
\hline & 10th centile & 35 & -0.0270 & 282 & -0.0219 & $-1.83^{*}$ & $-1.95^{*}$ \\
\hline & 90th centile & 35 & 0.0315 & 282 & 0.0295 & 0.71 & 0.59 \\
\hline \multirow[t]{6}{*}{ Balanced International } & mean & 20 & 0.0019 & 93 & 0.0028 & -1.62 & $-1.85^{*}$ \\
\hline & sd & 20 & 0.0230 & 93 & 0.0202 & 0.97 & 1.4 \\
\hline & skewness & 20 & -0.6490 & 93 & -0.2774 & $-2.09 * *$ & $-2.63^{* * *}$ \\
\hline & kurtosis & 20 & 3.5270 & 93 & 4.5119 & -1.48 & $-2.26^{* *}$ \\
\hline & 10th centile & 20 & -0.0292 & 93 & -0.0221 & $-1.77^{*}$ & $-2.2^{* *}$ \\
\hline & 90th centile & 20 & 0.0281 & 93 & 0.0252 & 0.82 & 1.46 \\
\hline \multirow[t]{6}{*}{ Domestic Equity } & mean & 6 & 0.0092 & 78 & 0.0089 & 0.21 & 0.19 \\
\hline & $\mathrm{sd}$ & 6 & 0.0467 & 78 & 0.0547 & -1.62 & $-2.52^{* *}$ \\
\hline & skewness & 6 & -0.3793 & 78 & -0.2657 & -0.92 & -0.76 \\
\hline & kurtosis & 6 & 3.6238 & 78 & 3.5981 & 0.09 & 0.14 \\
\hline & 10th centile & 6 & -0.0514 & 78 & -0.0577 & 0.92 & 1.48 \\
\hline & 90th centile & 6 & 0.0664 & 78 & 0.0796 & $-1.69^{*}$ & $-2.21^{* *}$ \\
\hline \multirow[t]{6}{*}{ European Equity } & mean & 30 & 0.0041 & 127 & 0.0027 & 1.4 & 0.69 \\
\hline & sd & 30 & 0.0520 & 127 & 0.0536 & -0.7 & -0.96 \\
\hline & skewness & 30 & -0.5571 & 127 & -0.5254 & -0.42 & -0.49 \\
\hline & kurtosis & 30 & 3.8517 & 127 & 3.8236 & 0.13 & 1.15 \\
\hline & 10th centile & 30 & -0.0654 & 127 & -0.0686 & 0.73 & 0.52 \\
\hline & 90th centile & 30 & 0.0626 & 127 & 0.0648 & -0.73 & -1.14 \\
\hline \multirow[t]{6}{*}{ Fixed Income } & mean & 34 & 0.0030 & 348 & 0.0041 & $-4.38 * * *$ & $-5.39 * * *$ \\
\hline & sd & 34 & 0.0035 & 348 & 0.0061 & $-2.5^{* *}$ & $-4.36 * * *$ \\
\hline & skewness & 34 & 0.1150 & 348 & 0.2447 & -0.73 & 0.71 \\
\hline & kurtosis & 34 & 4.8271 & 348 & 4.9765 & -0.16 & $-3.51^{* * *}$ \\
\hline & 10th centile & 34 & -0.0010 & 348 & -0.0030 & 1.48 & $3.08^{* * *}$ \\
\hline & 90th centile & 34 & 0.0068 & 348 & 0.0111 & $-3.84^{* * *}$ & $-4.68 * * *$ \\
\hline \multirow[t]{6}{*}{ Foreign Equity } & mean & 49 & 0.0002 & 211 & -0.0006 & 0.83 & 0.5 \\
\hline & sd & 49 & 0.0559 & 211 & 0.0573 & -0.51 & -0.09 \\
\hline & skewness & 49 & -0.4409 & 211 & -0.3844 & -0.86 & -0.61 \\
\hline & kurtosis & 49 & 3.4431 & 211 & 3.5884 & -0.96 & 0.19 \\
\hline & 10th centile & 49 & -0.0729 & 211 & -0.0765 & 0.81 & 0.71 \\
\hline & 90th centile & 49 & 0.0650 & 211 & 0.0659 & -0.28 & -0.08 \\
\hline \multirow[t]{6}{*}{ Money Market } & mean & 51 & 0.0038 & 159 & 0.0038 & 0.39 & -0.66 \\
\hline & sd & 51 & 0.0021 & 159 & 0.0020 & 0.29 & -0.25 \\
\hline & skewness & 51 & 0.9158 & 159 & 0.7330 & 1.02 & -0.13 \\
\hline & kurtosis & 51 & 4.3968 & 159 & 4.6830 & -0.26 & -0.53 \\
\hline & 10th centile & 51 & 0.0019 & 159 & 0.0017 & 0.87 & -0.53 \\
\hline & 90th centile & 51 & 0.0063 & 159 & 0.0067 & -0.87 & -0.49 \\
\hline \multirow[t]{4}{*}{ Global } & mean & 17 & 0.0022 & 165 & 0.0023 & -0.06 & -0.78 \\
\hline & sd & 17 & 0.0232 & 165 & 0.0253 & -0.45 & -0.42 \\
\hline & skewness & 17 & -0.5982 & 165 & -0.2578 & -1.47 & -1.51 \\
\hline & kurtosis & 17 & 6.7723 & 165 & 5.5984 & 1.22 & -0.14 \\
\hline
\end{tabular}


Table 16 - Continued from previous page

\begin{tabular}{llcccccc}
\hline \hline Category & measure & \multicolumn{2}{c}{ non-users } & \multicolumn{2}{c}{ users } & ttest & Wilcoxon \\
& & $\mathbf{N}$ & mean & $\mathbf{N}$ & mean & t-stat & z-stat \\
\hline & 10th centile & 17 & -0.0292 & 165 & -0.0286 & -0.1 & 0.41 \\
& 90th centile & 17 & 0.0279 & 165 & 0.0297 & -0.37 & -0.51 \\
\hline \hline
\end{tabular}

This table presents the four main central moments, the 10th and 90th percentiles of the funds' distribution of the before fee returns per category and group. Groups are non users and users of derivatives. A t-test and a Wilcoxon test are performed on the mean and median group values per category respectively. The central moments' measures are the returns' mean, the returns' standard deviation, the returns skewness, and the returns kurtosis. Returns are computed on a nonthly basis and the management fee and the deposit fees are added back. The sample covers the period at $5 \%$; *** significant at $1 \%$.

Table 17: Before Fees Return Distributions of Heavy Users.

\begin{tabular}{|c|c|c|c|c|c|c|c|}
\hline \multirow[t]{2}{*}{ Category } & \multirow[t]{2}{*}{ measure } & \multicolumn{2}{|c|}{ non-users } & \multicolumn{2}{|c|}{ users } & \multirow{2}{*}{$\begin{array}{l}\text { ttest } \\
\text { t-stat }\end{array}$} & \multirow{2}{*}{$\begin{array}{c}\text { Wilcoxon } \\
\text { z-stat }\end{array}$} \\
\hline & & $\mathbf{N}$ & mean & $\mathbf{N}$ & mean & & \\
\hline \multirow{6}{*}{ Balanced Domestic } & mean & 35 & 0.0031 & 50 & 0.0042 & -1.47 & $-1.87^{*}$ \\
\hline & sd & 35 & 0.0238 & 50 & 0.0225 & 0.47 & 0.62 \\
\hline & skewness & 35 & -0.4485 & 50 & -0.2544 & $-1.94^{*}$ & $-2.04^{* *}$ \\
\hline & kurtosis & 35 & 4.2059 & 50 & 3.9521 & 0.77 & 1.53 \\
\hline & 10th centile & 35 & -0.0270 & 50 & -0.0230 & -1.16 & -1.32 \\
\hline & 90th centile & 35 & 0.0315 & 50 & 0.0310 & 0.13 & 0.09 \\
\hline \multirow[t]{6}{*}{ Balanced International } & mean & 20 & 0.0019 & 17 & 0.0021 & -0.34 & -0.24 \\
\hline & $\mathrm{sd}$ & 20 & 0.0230 & 17 & 0.0205 & 0.64 & 1.49 \\
\hline & skewness & 20 & -0.6490 & 17 & -0.5674 & -0.65 & -0.15 \\
\hline & kurtosis & 20 & 3.5270 & 17 & 4.1352 & $-2.2^{* *}$ & $-1.83^{*}$ \\
\hline & 10th centile & 20 & -0.0292 & 17 & -0.0238 & -0.97 & $-1.65^{*}$ \\
\hline & 90th centile & 20 & 0.0281 & 17 & 0.0257 & 0.5 & 1.37 \\
\hline \multirow[t]{6}{*}{ Domestic Equity } & mean & 6 & 0.0092 & 15 & 0.0080 & 0.71 & 0.7 \\
\hline & $\mathrm{sd}$ & 6 & 0.0467 & 15 & 0.0613 & $-5.15 * * *$ & $-3.43^{* * *}$ \\
\hline & skewness & 6 & -0.3793 & 15 & -0.2725 & -1.09 & -0.7 \\
\hline & kurtosis & 6 & 3.6238 & 15 & 3.4088 & 1.41 & 0.7 \\
\hline & 10th centile & 6 & -0.0514 & 15 & -0.0674 & $2.82^{* *}$ & $2.18^{* *}$ \\
\hline & 90th centile & 6 & 0.0664 & 15 & 0.0896 & $-4.01 * * *$ & $-3.04 * * *$ \\
\hline \multirow[t]{6}{*}{ European Equity } & mean & 30 & 0.0041 & 28 & 0.0020 & 1.35 & 1.09 \\
\hline & $\mathrm{sd}$ & 30 & 0.0520 & 28 & 0.0563 & -1.65 & $-2.19 * *$ \\
\hline & skewness & 30 & -0.5571 & 28 & -0.6526 & 0.98 & 0.78 \\
\hline & kurtosis & 30 & 3.8517 & 28 & 3.8666 & -0.05 & 0.75 \\
\hline & 10th centile & 30 & -0.0654 & 28 & -0.0746 & $1.73^{*}$ & $1.73^{*}$ \\
\hline & 90th centile & 30 & 0.0626 & 28 & 0.0680 & -1.36 & $-1.76^{*}$ \\
\hline \multirow[t]{6}{*}{ Fixed Income } & mean & 34 & 0.0030 & 71 & 0.0043 & $-3.52^{* * *}$ & $-5.03^{* * *}$ \\
\hline & sd & 34 & 0.0035 & 71 & 0.0080 & $-3.56^{* * *}$ & $-5.15^{* * *}$ \\
\hline & skewness & 34 & 0.1150 & 71 & 0.1840 & -0.32 & 1.49 \\
\hline & kurtosis & 34 & 4.8271 & 71 & 4.5116 & 0.28 & $-2.6^{* * *}$ \\
\hline & 10th centile & 34 & -0.0010 & 71 & -0.0053 & $2.58^{* *}$ & $4.62 * * *$ \\
\hline & 90th centile & 34 & 0.0068 & 71 & 0.0133 & $-5.06^{* * *}$ & $-5.42^{* * *}$ \\
\hline \multirow[t]{5}{*}{ Foreign Equity } & mean & 49 & 0.0002 & 49 & -0.0024 & $2.13^{* *}$ & $2.31^{* *}$ \\
\hline & $\mathrm{sd}$ & 49 & 0.0559 & 49 & 0.0586 & -0.86 & -0.07 \\
\hline & skewness & 49 & -0.4409 & 49 & -0.3373 & -1.46 & -1.28 \\
\hline & kurtosis & 49 & 3.4431 & 49 & 3.1253 & $2.75^{* * *}$ & $2.84^{* * *}$ \\
\hline & 10th centile & 49 & -0.0729 & 49 & -0.0812 & $1.7^{*}$ & $1.64^{*}$ \\
\hline
\end{tabular}


Table 17 - Continued from previous page

\begin{tabular}{llcccccc}
\hline \hline Category & measure & \multicolumn{2}{c}{ non-users } & \multicolumn{2}{c}{ users } & ttest & Wilcoxon \\
& & $\mathbf{N}$ & mean & $\mathbf{N}$ & mean & t-stat & z-stat \\
\hline \multirow{3}{*}{ Money Market } & 90 th centile & 49 & 0.0650 & 49 & 0.0677 & -0.7 & -0.35 \\
& & & & & & & \\
& mean & 51 & 0.0038 & 40 & 0.0039 & -0.49 & $-1.7^{*}$ \\
& sd & 51 & 0.0021 & 40 & 0.0018 & 0.77 & -0.91 \\
& skewness & 51 & 0.9158 & 40 & 0.9214 & -0.03 & -0.67 \\
kurtosis & 51 & 4.3968 & 40 & 4.0074 & 0.36 & -0.1 \\
Global & 10th centile & 51 & 0.0019 & 40 & 0.0020 & -0.28 & -1.46 \\
& 90th centile & 51 & 0.0063 & 40 & 0.0067 & -1.1 & -1.36 \\
& & & & & & & \\
& mean & 17 & 0.0022 & 27 & 0.0013 & 0.5 & -0.33 \\
& sd & 17 & 0.0232 & 27 & 0.0276 & -0.64 & -0.47 \\
& skewness & 17 & -0.5982 & 27 & -0.5561 & -0.13 & -0.4 \\
& kurtosis & 17 & 6.7723 & 27 & 5.3952 & 0.89 & 0.54 \\
& 10th centile & 17 & -0.0292 & 27 & -0.0294 & 0.03 & 0.47 \\
& 90th centile & 17 & 0.0279 & 27 & 0.0294 & -0.25 & -0.35 \\
\hline \hline
\end{tabular}

This table presents the four main central moments, the 10th and 90th percentiles of the funds' distribution of the before fee returns per category and group. Groups are non users and heavy users of derivatives. Funds are defined as heavy users if their frequency of derivative use is larger than the 75 percentile and their average ratio of notional value in derivatives to net asset value is larger than the 75 percentile. A t-test and a Wilcoxon test are performed on the mean and median group values per category respectively. The central moments' measures are the returns' mean, the returns' standard deviation, the returns' skewness, and the returns' kurtosis. Returns are computed on a monthly basis and the management fee and the deposit fees are added back. The sample covers the period from March 1995 to March 2005 and funds with more than three years of monthly observations. Fund data is obtained from the Spanish Security and Exchange Commission, CNMV. ${ }^{*}$ significant at $10 \%$; ** significant at $5 \%$; ${ }^{* * *}$ significant at $1 \%$.

Our study of the distributions of returns does not improve the overall picture on derivatives usage. The use of derivatives is related to speculation rather than hedging, but speculators do not exhibit special talent in any category except in the Fixed Income segment. This category is the only one that survives both the performance evaluation and return distributions exercises we perform in this paper.

\section{Cash Flow Management vs. Incentive Gaming Hypothesis}

The incentive gaming theory in fund management states that if funds have bad (good) performance at the beginning of the evaluation period, they have an incentive to increase (decrease) the fund's risk as the final date of the evaluation period approaches. Hence the theory predicts that the changes in fund risk before the evaluation period are negatively correlated to the fund's previous performance. This theory has found empirical support in Brown et. al. (1996) and Koski and Pontiff (1999). In addition, 
in the fund literature, there is evidence that when funds perform well (bad) there is a tendency for the fund to receive new cash inflows (outflows) Ippolito (1992). These new cash flows, if large enough, can alter the risk profiles of the funds if the cash is not rapidly and efficiently spread out through the investment positions. Large cash inflows may have the effect of reducing the fund's risk, while large cash outflows may increase the fund's risk. Since cash inflows tend to increase with the fund's good past performance and cash outflows with the fund's bad performance, we have a second channel that links the fund's risk with the fund's past performance. But, if funds are allowed to used derivatives, these in turn could be used to reduce, even eliminate, the effects of cash in- and outflows on the fund's risk profile. This is the cash flow management hypothesis of Koski and Pontiff (1999).

In order to analyze if the evidence favors the incentive gaming theory or the cash flow management hypothesis, Koski and Pontiff (1999) propose the following regression equation:

$$
\Delta R i s k_{i, t}=\alpha+\beta_{1} D_{i}+\beta_{2} \operatorname{Perf}_{i, t-1}+\beta_{3} D_{i} * \operatorname{Per} f_{i, t-1}+\beta_{4} * R i s k_{i, t-1}+\Sigma_{j} \beta_{j} d_{u m m y}
$$

where $\Delta R i s k_{i, t}$ is the change in risk form the second to the first semester of the year, $D_{i}$ is a dummy variable which indicates the use of derivatives by fund $i$, $\operatorname{Per} f_{i, t-1}$ is the difference of the fund's mean return and the average mean return in the first semester for all funds in the same investment category, and Risk $k_{i, t-1}$ is the risk variable in the first semester. Finally, dummies are included for each time period, fund category, fund size, and the interaction of time-period and fund category. The analyzed risk measures are the six-month standard deviation, the six-month beta and the six-month idiosyncratic risk in the market model. Koski and Pontiff (1999) do the simplifying assumption, as in the previous literature, that the fund's evaluation date is the natural calendar year end. We follow the same assumption. In order to capture this in the model only the change in risk from the first to the second semester of each calendar year is considered. A weighted least squares (WLS) regression is 
used, where the weight is one divided by the standard deviation of the fund error of a first pass OLS regression. The WLS regression controls for fund heteroscedasticity.

The coefficient $\beta_{2}$ of the $\operatorname{Perf}$ variable relates performance and change in risk for funds that do not use derivatives. In support to the cash flow management hypothesis and the incentive gaming hypothesis, it is expected to find a negative coefficient. The coefficient $\beta_{3}$ gives the marginal effect of the interaction of derivative use and past performance on the change in risk. It is expected to find a positive $\beta_{3}$ coefficient in support of the cash flow management hypothesis and a negative coefficient in support of the incentive gaming hypothesis. The reason for including the lagged risk variable $R i s k_{i, t-1}$ in the regression specification is to control for measurement errors in the risk variables, therefore one would expect a reversion of the errors from one period to the next. The coefficient for this variable is expected to be negative.

Table 18 reports the results for both the OLS and the WLS regressions using three alternative lagged risk measures (standard deviation, beta and idiosyncratic risk) and controlling for size, dividend yield, fund categories, sub-period and the interaction of fund categories and sub-periods. ${ }^{19}$ As expected in all cases the lagged risk variable Risk $_{i, t-1}$ has a negative and significant coefficient. The performance coefficient $\beta_{2}$ is negative for all risk measures and regressions, and significant for all lagged risk measures and regressions except for the OLS regression with the idiosyncratic risk as the lagged risk measure. The interaction of past performance and derivative use is positive and significant for the standard deviation and beta as lagged risk measures, and it is negative but not significant for the idiosyncratic risk as the lagged risk measure. That is, the effect of past performance on change in risk is reduced for derivative users if risk is measured as the standard deviation or as the market exposure, beta. Therefore, the evidence is more supportive of the cash flow management hypothesis than the incentive gaming hypothesis. Observe also that the constant coefficient of

\footnotetext{
${ }^{19}$ Three official fund types, short term fixed income (RFCP), long term fixed income (RFLP) and money market (FIAMM), are excluded form the analysis since the estimation of the parameters beta and root mean squared for six-month periods presented several complications.
} 
the regression model is positive and significant for all lagged risk measures. We interpret this as evidence of a increase over time of the funds risk in the second semester relative to the first semester of the calendar year. Since the reduction in risk due to the use of derivatives is significant for the standard deviation and the beta as lagged risk measures, it seems that market index derivatives are the most likely instruments being used for cash flow management.

Table 18: Cash Flow Management vs. Incentive Gaming.

\begin{tabular}{|c|c|c|c|c|c|c|}
\hline & STD ols & STD wls & IDIO ols & IDIO wls & BETA ols & BETA wls \\
\hline Constant & $\begin{array}{c}0.015 \\
(0.029)\end{array}$ & $\begin{array}{c}0.202 \\
(0.049)^{* * *}\end{array}$ & $\begin{array}{c}0.057 \\
(0.020)^{* * *}\end{array}$ & $\begin{array}{c}0.474 \\
(0.040)^{* * *}\end{array}$ & $\begin{array}{c}0.202 \\
(0.044)^{* * *}\end{array}$ & $\begin{array}{c}0.090 \\
(0.078)\end{array}$ \\
\hline $\mathrm{D}$ & $\begin{array}{l}-0.003 \\
(0.006)\end{array}$ & $\begin{array}{l}-0.006 \\
(0.012)\end{array}$ & $\begin{array}{c}0.006 \\
(0.004)\end{array}$ & $\begin{array}{c}0.060 \\
(0.010)^{* * *}\end{array}$ & $\begin{array}{c}0.006 \\
(0.009)\end{array}$ & $\begin{array}{l}-0.026 \\
(0.017)\end{array}$ \\
\hline Perf & $\begin{array}{c}-0.301 \\
(0.046)^{* * *}\end{array}$ & $\begin{array}{c}-0.590 \\
(0.073)^{* * *}\end{array}$ & $\begin{array}{l}-0.025 \\
(0.034)\end{array}$ & $\begin{array}{c}-0.151 \\
(0.069)^{* *}\end{array}$ & $\begin{array}{c}-0.238 \\
(0.073)^{* * *}\end{array}$ & $\begin{array}{c}-0.535 \\
(0.109)^{* * *}\end{array}$ \\
\hline$D^{*}$ Perf & $\begin{array}{c}0.321 \\
(0.049)^{* * *}\end{array}$ & $\begin{array}{c}0.867 \\
(0.074)^{* * *}\end{array}$ & $\begin{array}{l}-0.035 \\
(0.036)\end{array}$ & $\begin{array}{l}-0.014 \\
(0.072)\end{array}$ & $\begin{array}{c}0.142 \\
(0.078)^{*}\end{array}$ & $\begin{array}{c}0.228 \\
(0.114)^{* *}\end{array}$ \\
\hline $\begin{array}{l}\text { Risk: } \\
\text { STD }\end{array}$ & $\begin{array}{c}-0.203 \\
(0.010) * * *\end{array}$ & $\begin{array}{c}-0.461 \\
(0.012)^{* * *}\end{array}$ & & & & \\
\hline IDIO & & & $\begin{array}{c}-0.499 \\
(0.009)^{* * *}\end{array}$ & $\begin{array}{c}-0.627 \\
(0.013)^{* * *}\end{array}$ & & \\
\hline BETA & & & & & $\begin{array}{c}-0.342 \\
(0.009)^{* * *}\end{array}$ & $\begin{array}{c}-0.573 \\
(0.013)^{* * *}\end{array}$ \\
\hline Observations & 7680 & 7680 & 7493 & 7493 & 7493 & 7493 \\
\hline R-squared & 0.66 & 0.63 & 0.48 & 0.57 & 0.36 & 0.38 \\
\hline
\end{tabular}

The table reports the results for the estimation of the Koski and Pontiff (1999) model where the change in risk is regressed on past performance (Perf), a dummy variable (D) indicating derivative use, the interaction of past performance and the dummy on derivative use (Dperf), and the lagged risk measure (Risk). The respective risk measures are the six month standard deviation (STD), the six month root mean squared error from a market model (IDIO), and the beta of the market model (BETA). The regressions control for log of assets, dividends, subperiods, for fund category and interactions of sub-period and fund category. Funds with outlying price patterns are eliminated. The fund types RFCP, RFLP and FIAMM are also eliminated, since their estimation parameter beta is too unstable for the six months estimation period. The dependent variable is the change in risk from the first semester of the calendar year to the second semester. The sample covers the period from March 1995 to March 2005. Fund data is obtained from the Spanish Security and Exchange Commission, CNMV. * significant at $10 \%$; ** significant at $5 \%$; ** significant at $1 \%$.

\section{Final Remarks}

This study provides a comprehensive analysis of derivatives usage in the Spanish mutual fund industry. Mutual funds in Spain are heavy users of derivatives. By 2005 more than $60 \%$ of the funds were users and held positions in derivatives whose notional represented an average $10 \%$ of the funds value. These funds tend to be funds that belong to a large family where other funds also use derivatives, funds that charge 
large fees, non-load funds, large funds and funds with low dividend yields. In general, the use of derivatives does not improve the performance of the funds. In only one out of eight categories (Fixed Income funds) we find some (very weak and not robust) evidence of superior performance. In most of the cases users underperform non users. Users do not seem to exhibit either superior timing or selectivity skills, but rather the contrary. The only exceptions are the Balance Domestic and European Equity categories that exhibit timing skills and Fixed Income that exhibit selectivity skills. We find no strong evidence of derivative use for hedging purposes. The exceptions are Balanced Domestic and Balanced International funds which we cataloged as superperformers since they attain a larger skewness and a larger mean with a lower risk (larger breakpoint for the lower 10\% tail). We find stronger evidence of derivatives being used either for speculative purposes or to mimic their non user of derivatives counterparts. In the case of speculation we only find evidence of successful speculation in the fixed income category. Finally, we find evidence of derivatives being used to manage the funds' cash inflows and outflows more efficiently.

The previous results, specially the ones on performance, configure a rather negative picture of derivatives usage in the Spanish mutual fund industry. One possible explanation is that users of derivatives charge very large fees. In fact, we show that this is part of the problem as users in some categories improve when we evaluate them using returns before fees. Another possible explanation is that our study is missing some important aspects of usage. For instance, for brevity of exposition we have focused on some of the most widely used performance measures, but we are not providing evidence on some others of interest. In particular we do not address performance in the context of conditional asset pricing models nor in the context of factor models that control for the value, size and momentum effects. On the other hand our study compares the average performance of users and non users of derivatives, which is equivalent to compare equally weighted portfolios of those funds. Since skillful derivative traders are expensive, it may be the case that only the largest funds can 
afford them. If this were the case, our methodology is under-weighting the importance of these funds. This calls for an analysis of value weighted portfolios of funds. These two are some of the extensions we plan to address in future research.

\section{A Appendix A}

Name and description of the official fund categories.

\section{Table 19: Description of Official Fund Categories.}

\begin{tabular}{|l|l|}
\hline Name & Description \\
\hline FIAMM & Euro denominated fixed income assets, with a max 5\% in non euro assets \\
\hline RFCP & Duration less than two years, with a max $5 \%$ in non euro assets \\
\hline RFLP & Duration larger than two years, with a max $5 \%$ in non euro assets \\
\hline RFI & No equities allowed, with a max $5 \%$ in non euro assets \\
\hline RFM & Less than $30 \%$ in equities, with a max $5 \%$ in non euro assets \\
\hline RVM & Between $30 \%$ and $75 \%$ in equities, with a max $5 \%$ in non euro assets \\
\hline RFMI & Less than $30 \%$ in equities, more than $5 \%$ in non euro assets \\
\hline RVMI & Between $30 \%$ and $75 \%$ in equities, and more than $5 \%$ in non euro assets \\
\hline RVN & More than $75 \%$ in equities traded in Spanish markets, with more than $90 \%$ in national assets \\
\hline RVE & More than $75 \%$ in equites, and national assets less than $90 \%$, a max of $30 \%$ in non euro assets \\
\hline RVIE RVIJ RVIU RVIM RVIO & More than $75 \%$ in equities, at least $75 \%$ in assets issued by either European, Japan, \\
\hline & USA, or Emerging markets, and Other issuers respectively and more than $30 \%$ in non euro assets \\
\hline FGL & Those funds that do not fit into any of the previous definitions \\
\hline
\end{tabular}

This table presents the official fund type definitions. Each fund in Spain is assigned to one of these fund types according to the fund's portfolio characteristics.

\section{A Appendix B}

In this section we briefly described some of the errors we have found in the fund data set and the criteria followed in trying to fix them.

- Reported values of notional and market value of derivatives positions. In most of the cases funds report the same figure for the notional and the market value of the position. In some cases they report one of them takes the value zero and the other a positive value. In a few cases negatives values were found. We decided to use the absolute value of the reported market value as the notional of the position. 
- Typing errors for the notional amount and the market value for derivative positions. In some quarters we observed obvious typing errors. The information should be reported in thousands, but positions were introduced in units. Correction: The general procedure to fix this is to take the aggregate sum of the derivative positions and if they were greater than the total net asset value of the fund, the position was divided by 1000 .

- Prices captured after death of funds: the share asset prices for some funds are reported after the official date of the fund's deregistration. Correction: A list of official date of deregistration was created for some funds, and any price falling after this date was eliminated.

- Problems in reporting prices for mergers or acquisitions:If a fund merged with others, in some cases prices continue to be reported for the merged fund or acquired fund after the merger date. Moreover, the price series typically show a clear discontinuity. For the series for which such a discontinuity was detected, the series is dropped out of the sample.

- Some funds where detected to have strange price patterns, one example is one fund whose price did not change through a long period of time. Such type of funds were eliminated. 


\section{References}

BIS (2001), 'Central bank survey of foreign exchange and derivatives market activity in april 2001: preliminary global data', BIS publications .

BIS (2004a), 'Quarterly review on derivatives, september 2004', BIS publications pp. 1-8.

BIS (2004b), 'The triennial central bank survey of foreign exchange and derivatives market activity in april 2004', BIS publications pp. 1-22.

Brown, K., Harlow, W. V. and Starks, L. T. (1996), 'Of tournaments and temptations: An analysis of managerial incentives in the mutual fund industry', The Journal of Finance 51, 85-110.

Chevallier, J. and Ellison, G. (1997), 'Risk taking by mutual funds as a response to incentives', The Journal of Political Economy 105, 1167-1200.

Ferson, W. and Shadt, R. W. (1996), 'Measuring fund strategy and performance in changing economic conditions', The Journal of Finance 51, 425-461.

Greene, W. H. (1993), Econometric Analysis, Macmillan, New York.

Ippolito, R. A. (1992), 'Consumer reaction to measures of poor quality: Evidence from the mutual fund industry', Journal of Law \& Economics 35(1), 45-70.

Johnson, L. D. and Yu, W. W. (2004), 'An analisis of the use of derivatives by the canadian mutual fund industry', Journal of International Money and Finance 23, 947-970.

Koski, J. L. and Pontiff, J. (1999), 'How are derivatives used? Evidence from the mutual fund indsutry', The Journal of Finance 54, 791-816.

Marín, J. M. and Rubio, G. (2001), Economía Financiera, Antoni Bosch, Barcelona. 
Pinnuck, M. (2004), 'Stock preferences and derivative activities of Australian fund managers', Accountinf and Finance pp. 97-120.

Shanken, J. (1990), 'Intertemporal asset pricing: An empirical investigation', Journal of Economterics 45, 99-120.

Treynor, J. and Mazuy, K. (1966), 'Can mutual funds outgess the market?', Harvard Business Review pp. 131-136.

Tschoegl, A. (2003), The key to risk management: management in "Risk management: challenges and opportunities", M. Frenkel, U. Hommel (eds.), Srpinger Verlag. 